\title{
1996 年春季大会記事
}

1996 年春季大会は，5月 18 日（土） 19日（日）の 2 日間にわたって，仙台市戦災復興記念館において開 催された。両日にわたり行われた研究発表では，43 件 (自然 23 件，人文 20 件)の研究が報告され，活発に討 議された。研究発表には 150 名の参加者があった。18 日の夕方には参加者 50 名により懇親会が行われ, 会員 相互の親睦がはかられた。また，評議会が 18 日，総会
が19日に開催された。

19 日の午後に実施した「東北大学理学部自然史標本 館」の見学には 18 名が参加し，同館展示の外邦図 (旧 陸軍参謀本部および陸地測量部が作成した外国の一般 図),および約 9 万枚に及ぶ外邦図を保管する収蔵庫を 田村俊和会員（東北大学）の案内で見学した。

以下に研究発表の要旨を掲載する。

\section{一般研究発表要旨}

松浦 旅人（東北大・院）：琵琶湖北岸，野坂山地における谷中分水界の移動と河川の流路変更

小松原 琢（地質調査所）：庄内平野東縁で見い出された活褶曲の変位形態の変化について

大月 義徳（東北大）：奥羽脊梁山脈東緑，作並一屋敷平断層の活動時期

栗山 知士 (五城目高) : 旧八郎潟東岸・井川付近の活断層

松本 秀明 (東北大) ・渡辺 信孝 (東北大・学) : 仙台平野中部名取川周辺の沖積層基底礫層について

伊藤 晶文 (東北大・院)：石巻平野北部の埋没地形の形態

菊地立 (東北学院大) : 屋敷林をもつ農家の気温特性

二瓶 由子。佐藤 裕子・菊地立（東北学院大）：仙台市海岸部における現存屋敷林

清野＼cjkstart茂（宮城県保健環境センター）：南蔵王南西麓周辺の河川（横川水系）の水質特性

小荒井 衛 (環境庁) : 衛星リモートセンシングで把握した東北地方の植生改変状況

佐々木明彦 (東北大・院)・苅谷 愛彦 (地質調査所) : 三国山地平標山に分布する埋没泥炭層の ${ }^{14} \mathrm{C}$ 年代とそれに 介在するテフラの給源

吉木 岳哉（東北大・院）：広島県北部の山地地域にみられる完新世初頭の年代を示す化石崩壊地形

山本憲志郎 (筑波大)：トマムの $11^{\circ} \sim 17^{\circ}$ の山麓斜面の物質移動様式と斜面発達

岩船 昌起 (東北大・院) ・岩田 修二 (都立大)・池田 明彦 (品川区役所) ・川口 裕輔 (東北大・院)・加藤 仁 美・山下 浩樹 (東北大・学)・福井幸太郎・前田＼cjkstart豊（東京学芸大・学）：上高地，梓川河床にお ける 1995 年 7 月上旬の豪雨による地形変化 (速報)

籠瀬 良明 (黒部川扇状地研究所)：三態様の自然堤防調査における相違と相似

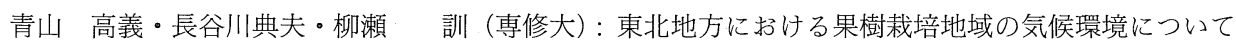

古谷 尊彦 (千葉大)・渡辺 慈明 (ドリコ(株)：東頸城丘陵の地すべり地形とその分布

李 穎・松林武 (東北大・院)・田村 俊和（東北大）：高舘丘陵におけるプレ1994年崩壊の発生年代（英 文)

馬場 俊行（東北大・院）：名取市高舘丘陵における 1994 年 9 月豪雨時の土砂生産量と流域地形特性

松林＼cjkstart武（東北大。院）：丘陵地小流域における植生と地形との対応関係

一高舘丘陵，川内沢川上流部を事例に一

興野 寛久 (足利商高) ・阿子島 功 (山形大) : 天童市ジャガラモガラ冷気湖の熱収支について

村田 英彦 (東北大・院)：ヒートアイランド強度の日変化・年変化 一都市の周囲が水田の場合一

田坂 郁夫（福井工大）：都市内丘陵周辺の気温分布

千葉 明彦 (東北学院大)：盛岡都市圏における大規模宅地開発の展開

青柳光太郎 (東北学院大)・鈴木 希 (株セント)・新田 将人（仙台市立三条中）・本間 章彦（村上市立大栗

田中) : 都市化に伴う土地利用変化と地形条件 一仙台都市圏における GIS を用いた分析一

増田聡・村山 良之 (東北大)：活断層沿いの土地利用規制をめぐる問題点

牧之瀬泰志（東北大・院）：山形県における金融の地域構造 
平出 雅彦（東北大・院）：宮城県北部地域に抢ける交通現象変化 一その要因と影響一

川口裕輔（東北大・院）：新潟県湯沢町におけるリゾートマンション景観形成に関する一考察

松村 公明（秋田大）：仙台市に扔ける宿泊機能の立地動向

伊藝 直哉（東北大・研）：東京都大田区に扔ける中小工場の存続形態 一矢口・下丸子地区を事例に一

鈴木 貞夫 (内郷高)：福島県浜通り地方中南部の東海道（古代道）の想定

安田 初雄: 近世阿武隈川舟路の本内河岸・鎌田河岸について

金安 岩男 (慶應大) : システムインテグレーターと地理学 一環境情報社会論序説一

今野 修平 (大阪産業大) : 環境問題の認識と交通政策の変化

辻＼cjkstart正行（東北大・院）：メキシコにおける人口増加，国内人口移動に関する知見

星野 忠祐（愛知教育大・院）・石澤 孝（信州大）：中部日本に扔ける出生率の地域的差異とその要因

竹内 元生 (東北大・院)：農地の買収・壊廃にともなう農家対応の実態 一長野市長沼地区の場合一

菊地 俊夫 (都立大) - 堤 純 (北海道大) : 都市近郊農村に扔ける農業的土地利用の持続性と変移性 一前橋市近郊の養虫農村の事例一

関根 良平 (東北大・院)：福島県高郷村における農家の兼業化進展過程

中川重（山形大）：新都市計画法と都市化の進展

大友 篤（日本女子大）: 都市内事業所密度の法則

遠城 明雄（東北大）：都心社会の変動と「町抗こし」運動 一「伝統的なるもの」をめぐって一

\section{琵琶湖北岸，野坂山地における谷中分水界の移動と河川の流路変更}

\section{1.はじめに}

野坂山地は琵琶湖北岸から若狭湾岸にかけて位置す る。山地を流れる河川は琵琶湖または日本海に注ぐが, 上流部において 2 つの水系の多くは谷中分水界で接す ることが認められる。この原因として断層活動と河川 争奪に起因する従来の考えは地款変動を偏重してお り，再検討すべき点が多い。

従って今回の調査は野坂山地の地形発達史の一環と して, 第四紀中・後期に扔ける地殼変動・気候変動と それに伴う河川の性格の変化を考察する。すなわち河 成段丘の分布やその性格から古水系を復原し，次に谷 中分水界の移動と河川の流路変更を規定した要因と時 代について検討することを目的とする。

2. 谷中分水界の位置決定について

対象地域において，現谷中分水界をのせる平坦面は 次のような特徴がある。

1）日本海水系に属する。

2）上流 (南)に対して開口し, wind gap で終わっ ている。

3）構成層に AT が含まれることから，L1 面(約 2 万年前に形成）に分類される。

従って谷中分水界より南方に抢いて, 琵琶湖水系に 対して逆傾斜している段丘（面または基底面）からか つての谷中分水界の位置と古水系が復原できる。ただ し複数の逆傾斜段丘がある場合，時代の違うそれぞれ

\section{松 浦 旅 人（東北大・院）}

のイベントを考えなければならない。

3. 五位川 (日本海水系)一知内川 (琵琶湖水系) の 例

古五位川本流の逆傾斜段丘は残存されていないた め，その支流からかつての谷中分水界を推定する。五 位川の支流 (L1 面) と知内川の支流プロファイルを比 較する。後者は知内川にアジャストしつつあるが，水 流方向・勾配ともに前者と酷似し，谷中分水界をのせ る L1 面に連続する。従って L1 面時の谷中分水界は約 $2.5 \mathrm{~km}$ も南に位置していたことがわかる。

L2 面は知内川に同調するため, 流路変更は L1 面形 成後，L2 面形成前になる。

Hat 面は五位川を越えて知内川流域にも分布して いるが, 谷中分水界の位置を知る情報は十分ではない。

4. 新道野川（日本海水系）一大浦川・大川（琵琶湖 水系) の例

現在の谷中分水界（新道野集落付近）から集福寺活 断層系までの L1 面は大川に逆傾斜している。従って 2 万年以降，谷中分水界は $750 \mathrm{~m}$ も北進した。

Hat, Has 基底面が断層によって受けた変位は約 40 m である。従って変位を受ける前の Hat, Has 段丘基 底面コンターを作成すると次のことがわかる。

1）古新道野川は現在よりも $3 \mathrm{~km}$ ほど南に谷中分 水界をもっていた。

2）大川は Hat, Has 基底面形成時においても琵琶 
湖水系であり,古新道野川と比べて河床高度が低く,勾 配も急であった。

従って Hat, Has 面層の埋積が始まると河床が押し 上げられ，大川への水路が形成された。この時断層変 位が引き金になった可能性がある。埋積作用が衰退す ると大川沿いの Has 面は基準面にアジャストしたた め fill strath 段丘と考えられる。
以降大川は集福寺断層系に沿って河川争奪を繰り返 した。

\section{5. 課 題}

Hat, Has 段丘の年代（更新世中期）に関する試料が 得られていない。

※ Hat-Ha fill top 段丘, Has=Ha fill strath 段丘

\section{庄内平野東縁で見い出された活襀曲の変位形態の変化について}

\section{1.はじめに}

庄内平野の東緑部には, 複数の活褶曲が並走する。こ れらの活褟曲について, 地質学的に活動過程を明らか にすると共に，段丘基盤をなす上部新生界の構造と段 丘面の変位形態を比較することによって, 活褶曲の変 位形態の変遷を論じた。

\section{2. 地域概要}

庄内平野東縁には, 東 (出羽山地寄り) 加青沢断 層群-青沢複背斜 ( $\mathrm{A}-\mathrm{A})$, 酒田衝上断層群- 北俣背斜 $(\mathrm{S}-\mathrm{K})$, 生石断層-平田背斜 $(\mathrm{O}-\mathrm{I})$ の 3 つの逆断層-背 斜構造が並走する。このうち, A-A は鮮新世末期ごろ に， S-K は前期更新世ごろに，O-I は中期更新世以降 に活動を開始し，それぞれ鮮新世末期から第四紀前半， 中期更新世前半，中期更新世後半期以降に最も活動が 活発であったと考えられる。

3. 活褶曲の変位形態の変遷

A-A では, 新第三系が背斜東翼の青沢断層近傍で大 きく変位する箱型の断面形を呈する一方で，段丘面は 青沢断層付近で小規模な断層変位を示す以外，緩やか な背斜状の変形を示す。

一方，O-I では中部更新統下部が比較的対称的な断 面形を呈し，それを覆う中部更新統上部や段丘面の背 斜軸は中部更新統下部の背斜軸よりも西に位置するほ か, 背斜西翼で急傾斜する非対称な断面形を呈する。さ らに, 新期の段丘面ほど背斜西翼の西側 (平野前縁部) の限られた範囲でのみ急傾斜する傾向が認められる。 また，活動過程の点で両構造の中間に位置すると考

\section{小松原琢（地質調査所）}

えられる S-K では，地質構造から言っても，段丘面の 変位形態と基盤構造の点から言っても両構造の中間に 位置づけられる。

以上のような段丘基盤と段丘面の変位形態の違い は，(1) 褶曲の成長初期段階では伏在断層の上盤側翼 部への背斜軸の移動と形態の非対称化，および上盤側 翼部における傾動運動の局所化が生じていること，(2) 十分に成長した褶曲では，逆にタイトな変形様式から ブロードな変形へと変位形態の変化が生じているこ と，を示す。

以上のような変位形態の変化は, 伏在する逆断層の 活動様式を反映した地表变位形態の変化として捉える ことができる。

すなわち, O-I のような新期の褟曲では, かなり急速 に（地形学的年代尺度で観察可能な速度で）逆断層先 端が地表に向かって延伸する（fault progradation）た め, 上記のような地表変位形態の変化が生じる。逆に A-Aのように既に盆地側に新たな構造が形成され，活 動が減衰傾向にある構造では, thrust front migration に伴って地下浅部における断層の活動が停止または減 衰することに伴って，地下深部の逆断層運動を反映し たブロードな変形が卓越するようになる。

このような地表変位様式の変化は，地下の断層運動 様式を知る上で貴重な手がかりを与えてくれると考え られる。今後, 地下構造の把握や力学的な解析を通じ て，この問題にアプローチしたい。 


\section{奥羽脊梁山脈東緑，作並一屋敷平断層の活動時期}

東北日本弧の中軸に位置しその主要な地形的骨格を なす奥羽脊梁山脈は，各所において東西緑を逆断層に 限られ，少なくとも新第三紀末以降，それらの活動に 伴う顕著な隆起带として成立している。仙台市西方 25 $\mathrm{km}$ 付近に位置する作並一屋敷平断層（谷ほか，1969） は，広義の仙台平野(仙台市街西方の丘陵地帯を含む) と奥羽脊梁山脈とを画する西上がりの高角逆断層であ る。当断層の走向はほほ南北, 地質断層としての総延 長は $25 \mathrm{~km}$ 強 (天野，1980), そのうち活断層として認 定される部分は約 $15 \mathrm{~km}$ (活断層研究会，1980, 1991) に及ぶ。本研究は, 未だ調査途上にあるものの, 周辺 地域の地形地質編年に基づき, 作並一屋敷平断層の活 動期を検討することを目的とするものである。

対象地域に抢ける上部新第三系〜第四系の層序は図 示される通りである。本地域の新第三系は大局的に, 海 成砕屑岩・火砕岩類を主とする下部中新統～中部中新 統，陸成酸性火砕岩類を主とする上部中新統～鮮新統 とに区分され，さらにこれらに貫入する流紋岩を主と する岩体・岩脈が認められる。第四系である芋峠層は, 仙台付近の最高位地形面, 本砂金面群を構成する堆積

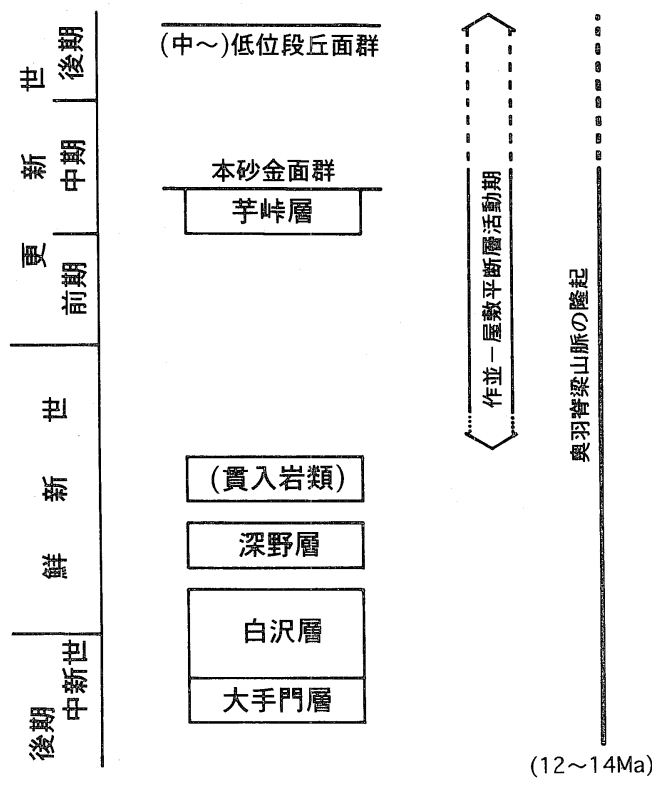

大 月 義 徳（東北大）

物で, 脊梁山脈起源の大〜巨碩を主体とする淘汰不良 の扇状地性堆積物からなる。芋峠層の基盤をなす深野 層（陸成鮮新統とされる）・ は, 軽石質粗粒凝灰岩や火 山礫凝灭岩・凝兏角砂岩など酸性火砕岩類を主体とし， 時に亜炭などを挟む。同層は，一般に 10 度内外と緩く 傾斜するが，作並一屋敷平断層近傍に扔いては傾斜 70 90 度の急斜帯が形成されている。

天野（1980）によれば，奥羽脊梁山脈の隆起帯とし ての萌芽は, 日蔭層（中部中新統）中に存在する脊梁 山脈起源と推定されるグリーンタフ礫の混入層準に認 められそその時期は BLOW（1969）による浮遊性有孔 虫化石帯 N11 N12 zone（約 12〜14 Ma：尾田, 1986）頃と考えられている。また作並一屋敷平断層の 活動開始期については, 確証に乏しいとされながらも， 後期中新世の白沢層堆積期頃と推測されていた (天野, 1980)。しかしながら本地域には, 前述したように，よ り上位の深野層を貫く高角な流紋岩 ( 安山岩) 岩体・ 岩脈が存在する。よって, 最小圧縮主応力軸 $\sigma_{3}$ が水平 面内に配置されていたであろう岩脈形成当時の造構応 力場の下で, 作並一屋敷平断層の逆断層としての活動 を想定することは困難と考えられる。換言すれば，第 四紀とほぼ同傾向での断層活動の下限年代は，流紋岩 を主とする深野層への貫入岩類の年代に示されている 可能性が大きい。

作並一屋敷平断層の第四紀における活動状況につい ては，次のように考えられる。芋垰層が脊梁山脈起源 の不淘汰粗粒堆積物で構成されることから, 少なくと も同層堆積時までに，春梁山脈の起伏量は増大してい たと判断される(大月, 1994)。また活断層研究会 (1980, 1991）は，川崎町本砂金付近にて芋峠層の断層変位露 頭の存在を報告している。これらを併せて考慮すると， 少なくとも本砂金面群形成期（中期更新世前半ないし 初頭と思われる）以後まで，本断層の活動により奥羽 脊梁山脈は継続的に隆起し，同山脈と広義の仙台平野 との地形的分化は進行したと推察される。

今後, さらに詳細な調査が必要とされるが, とりわ け深野層に貫入する火成岩類の年代把握は，東北日本 弧中部に抢ける後期新生代末期の造構環境を詳しく解 明する上でも重要と考えられる。

図作並一屋敷平断層周辺地域における上部新生界 層序と断層活動時期 


\section{旧八郎潟東岸・井川付近の活断層}

栗 山 知 士（五城目高）

旧八郎潟東岸の井川付近の活断層について, 演者は, 藤岡・高安（1965）の地質断層である井川断層の活動 に伴って形成された変位地形を認め, その変位地形の 特徵とその第四紀後期の断層運動の特徵を明らかにし た。

本地域の中小河川の井川流域には，河岸段丘の発達 が良好で, 高位より綱木沢面, 仲台面, 八田大倉面, 井 内 I・II 面に区分される。これらの段丘面の配置を概観 すると，井川断層の活動に伴って変形したのではない かと考えられる NE-SW 方向に伸びる西落ちの断層 変位地形が, 丘陵の一部, 綱木沢面, 仲台面に認めら れる。井川断層は，その副次的断層である東落ちの断 層を伴って, 地塁状の地形変形の累積として認められ る。また，綱木沢面には，東落ちの断層運動によるふ くらみ状の地形が認められる。この断層は, 活断層研 究会（1991）の綱木沢断層と考えられる。

現地調查で，4箇所の仲台段丘堆積物を切る井川断 層の主断層の露頭と完新統を切る断層露頭を発見し, そのすべてが逆断層であることが認められた。また,高 位の綱木沢段丘堆積物を切る小断層の露頭も数箇所認 められ, 一部の地形と露頭には, 撓曲状変形の箇所も 認められた。

以上のことから, 井川断層は, 確実度 I の活断層であ り，第三紀の地質断層が，第四紀に再活動したものと
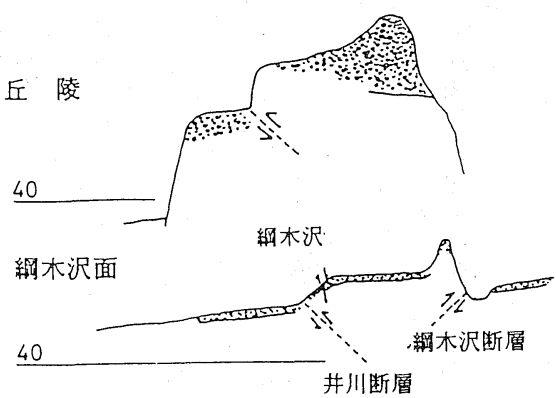

仲台

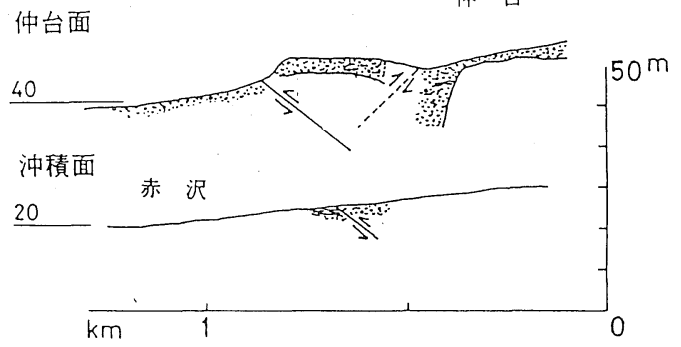

図 井川断層, および綱木沢断層の地形断面図

考えられ，その第四紀後期の活動も活発であったもの と考えられる。

\section{仙台平野中部名取川周辺の沖積層基底磁層について}

名取川沿いの地域（図）では旧石器時代から弥生時 代を中心とする遺跡である富沢遺跡をはじめ多くの遺 跡の発掘調查が行われている。富沢遺跡では地表面下 $4 \mathrm{~m}$ （7 m a.s.1.） から旧石器時代の遺物。遺構とともに 当時の地表面にあたる土層からトウヒ属, モミ属, カ ラマツ属およびハンノキ属の多数の根株が発掘され， 花粉分析や ${ }^{14} \mathrm{C}$ 年代測定結果等をもとに約 19,000 yBP〜24,000 yBP 頃の地表環境が復元されている（豊 島, 1992 ; 能城・鈴木, 1992 ; 守田, 1992 ほか)。その ほか，当地域では地下鉄建設をはじめとする各種土木 工事が行われるなど，近年地下の情報が多く蓄積され ている。
松本秀明（東北大）・渡辺信孝（東北大・学）

同地域の地表は名取川河道部分を中心に，砂碟が卓 越する扇状地状の地形が広がり，その縁辺部は腐植物 を多量に含むシルト〜粘土からなる低湿地に移行して いる。これらの地下には $40 \mathrm{~m}$ (+10 m 付近から -30

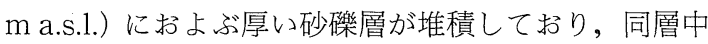
には少なくとも 3 枚の有機質シルト〜粘土層が挟み込 まれており, 砂礫の堆積途上において複数の堆積休止 期が存在したものと考えられる。本研究では, 考古学 的遺物等の産出状況やこれまで公表されている年代值 （上記の他に仙台市・国際航業，1983; 松本，1985; 小 元，1992）抢よび新たなボーリング資料の解析をもと に, 約 26,000 年前頃に堆積が終了していたと考えられ 


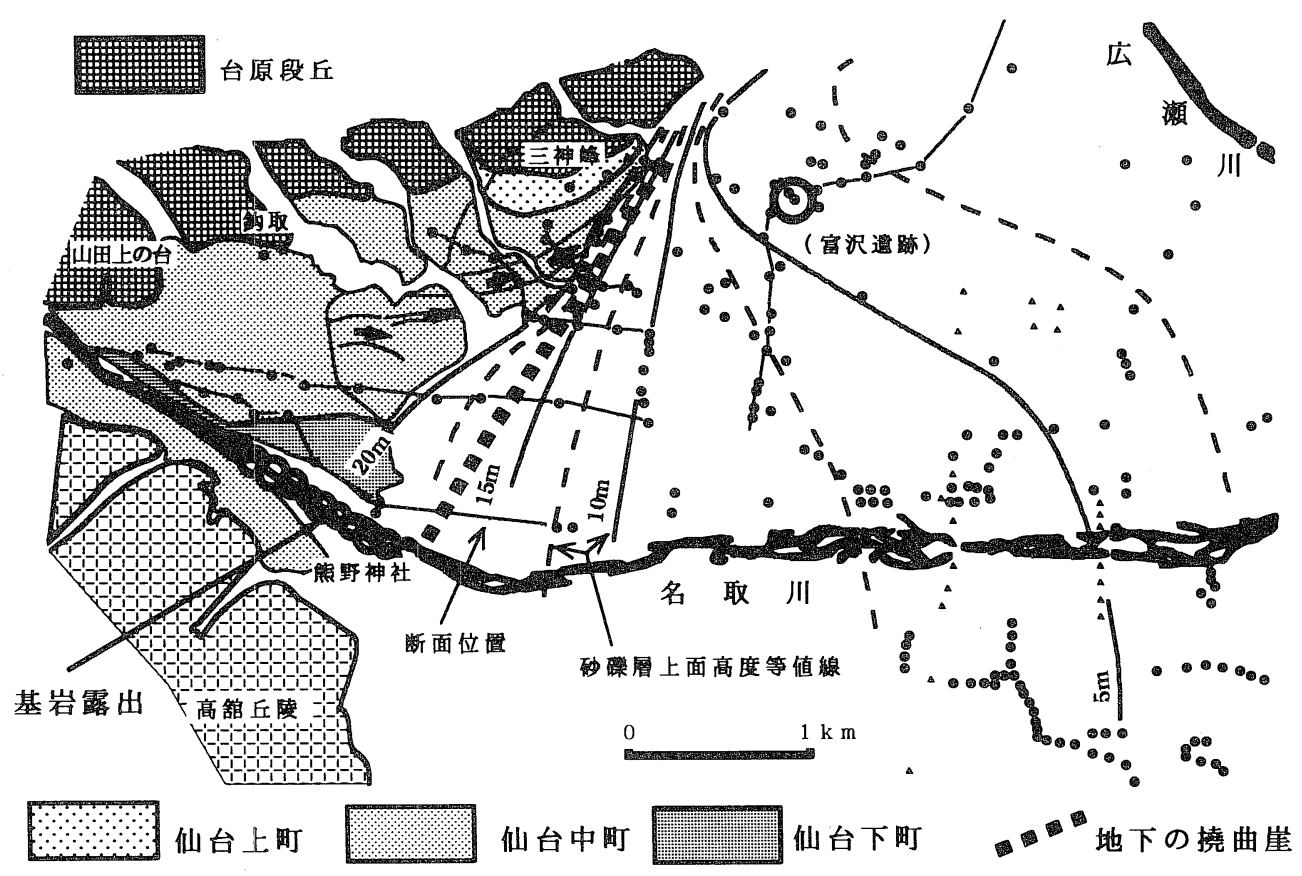

図 約 2 万 6 千年前に堆積を終了した砂礫層上面高度分布

る砂礫層の存在をこれらの中から見い出し, その上面 高度分布を復元する作業を行った。同砂砂層の層厚は 3〜 $5 \mathrm{~m}$ であり, 礫は 4 10 cm のものを主体として標 準貫入試験值は 40 前後あるいは 50 以上である。

上の作業を通じて，同砂砂層の分布状態が求められ るとともに，沖積低地の上流側に隣接して分布する河
岸段丘との関係を考察する資料が得られた。また，沖 積低地部と河岸段丘面とにまたがるいくつかの東西方 向の地下断面において, 長町一利府線の延長部と考え られる基盤岩のたわみ込みによる東落ちの崖地形が地 表面下に見いだされた。

\section{石巻平野北部の埋没地形の形態}

\section{I. 目的および方法}

石巻平野は，宮城県北東部に位置し，南北約 $50 \mathrm{~km}$ に及ぶ広大な沖積平野である。当平野には，主に北上 川, 迫川, 江合川の三河川が流入しており, 自然堤防, 旧河道の分布から，自然状態においては汇濫時に自由 に流路を変えながら, 当平野を形成したと考えられる。 当平野は従来から研究が行われており, 長谷 (1967) は, 沖積層中の海成粘土層の追跡と縄文貝塚の分布か ら, 縄文海進が河口から約 $45 \mathrm{~km}$ 内陸の若柳付近に及 んだことを示し, Matsumoto（1981）は, 海岸線の変化 を指標として当平野の形成過程を示した。これらの研 究では, 現在の連続的な低地の広がりから一連の流域

\section{伊 藤 晶 文（東北大・院）}

として当平野を捉え, その形成過程が示されている。し かし, 石巻平野北部（若柳，佐沼，中田付近）は，山 地および丘陵の分布をみると，丘陵および山地に四方 を囲まれており, 最終氷期最盛期以降の堆積物が堆積 する以前は, 個別の堆積域であったと考えられる。ま た，この地域の北上川と迫川の古流路については未だ 不明であり, 本研究では, ボーリング資料を用いて最 終氷期最盛期以降の堆積物に埋積された地形の原形態 を復元することによって, 本地域が個別の堆積域で あったことを確認し，さらに北上川，迫川の古流路の 位置に関する情報を得ようとするものである。 


\section{II. 結果扔よび考察}

ボーリング資料に基づいて，着岩深度分布図を作成 した。本地域の沖積層の基盤岩は主に，覀炭を挟むシ ルト岩, 砂岩, 凝灭岩からなる鮮新統の瀬峯層と, 粘 板岩からなる先第三系の登米層である。これらの深度 は柱状図記載の岩相や貫入試験值を基に判別すること ができる。しかし，風化によって比較的軟弱になって いると思われる岩相が，西野から無栗沼付近に見られ この付近の判別は困難であった。

着岩深度の状態から, 本地域北西部では丘陵間に標 高 $-30 \mathrm{~m}$ に埋没谷底が認められ, それに続く下流部の 現在の迫川の流路付近には標高 $-50 \mathrm{~m}$ に埋没谷底が 認められる。本地域中央部および東部にも標高 $-50 \mathrm{~m}$ の埋没谷底が存在し, 迫川が現在通過している本地域 南部の丘陵間に挟まれた挟部では, 標高 $-10 \mathrm{~m}$ 以浅の 分水界が認められる。

本地域の南方の平野 (西野, 柳津, 豊里, 飯野川付 近)の埋没地形についてもその形態の復元を行ったが,
柳津付近で二つの流路に分かれる北上川の河谷に標 高－60 m の埋没谷が存在している。飯野川から追波湾 にかけての河谷には，標高 $-70 \mathrm{~m}$ から $-80 \mathrm{~m}$ の埋没 谷が認められ，阿子島（1968）が示した結果を確認し た。西野付近の平野では, 平野中央部に位置する丘陵 の北部抢よび南部に標高 $-30 \mathrm{~m}$ の埋没谷が存在する。 西野付近には標高 $-20 \mathrm{~m}$ から $-10 \mathrm{~m}$ の埋没丘陵が存 在する。

以上の結果は次のようにまとめられる。

1）迫川は，沖積層堆積初頭は東西方向の流路を持 ち，現在の北上川の流路に対しほぼ直角に西方から合 流していたが，その後の縄文海進によって形成された 内湾を埋積する過程において現在の南北方向の流路に 転じた。

2）本地域は，縄文海進によって内湾が形成された 完新世初期までは一つの独立した沖積層の堆積域で あった。

\section{屋敷林をもつ農家の気温特性}

菊地立（東北学院大）

屋敷林は伝統的農村景観を形づくる重要な要素の一 つであり，地理学ではよく知られた事象である。その 背景や存立意義，活用面については多岐にわたる（三 浦：1992）が，そのひとつに防風林としての機能があ ることは明かである。しかし，実際に観測した例は意 外に少なく，実態は必ずしも把握されていないと思わ れる。仙台平野は屋敷林が多く，その規模も雄大で典 型的な屋敷林（地方名：イグネ）地域であるところか ら, 代表的と思われる農家に抢いて気温を中心に調查 を試み，屋敷林の影響を考察した。

調査地点は宮城県名取市高柳の T 氏宅で, 約 1,800 坪の屋敷の中央に母屋と納屋兼若夫婦の住居があり, 北側と西側に樹林が蓄えられている。屋敷林の外側は 水田である。調査期間は 1992 年 1 月 14 日から 3 月 9 日の 56 日間で, 数回の積雪があったが, 期間全体とし ては水田も，屋敷内の庭抢よび畑も裸地の状態であっ た。気温観測にはサーミスタ温度計（コーナシステム 社製 6 点記録夕イプ）を用い，屋敷内外をカバーする ように 20 地点の地上 $1.5 \mathrm{~m}$ の高さで 10 分間隔の記録 を行った。風速観測には風杯型微風速計 (牧野応用測 器社製マイクロアネモ) を用い，風杯の回転数を 1 分 間隔で記録させた。風速の観測は母屋の前庭および屋
敷林の北西外側水田の 2 地点である。気温を測定した 56 日間の内，仙台管区気象台の記録で降水のあった 日, 日平均雲量 8.5 以上, 日最低気温が $0^{\circ} \mathrm{C}$ 以上の温暖 日を除いた 41 日間を解析対象日とした。

本調査から次のような結果が得られた。

（1）日平均気温は屋敷内外の差が小さかった。時刻 別平均気温は, 早朝 6 時には屋敷内前庭で低く屋敷林 内で高い分布となり両者の気温差は $1.4^{\circ} \mathrm{C}, 14$ 時には 逆に林内で低温, 前庭で高温の分布となりその差は $3.1^{\circ} \mathrm{C}$ となった。また, 気温日較差は前庭で最大 $14.9^{\circ} \mathrm{C}$ に達し， $8.9^{\circ} \mathrm{C}$ にとどまった林内との差は $6.0^{\circ} \mathrm{C}$ になっ た。

（2）屋敷林を横断する線上の地点を選んで気温変 化を見ると，前庭の昇温域とは別に，午前中は屋敷林 の東側で昇温が早く, 正午頃から午後にかけて西側で 高温であった。

（3）仙台管区気象台の日平均風速をもとに, 解析対 象日の 41 日を相対的強風日と弱風日に分けて平均気 温を求めると, 屋敷林の外側の水田では弱風日に比べ 強風日は夜間の気温は高く, 日中の気温は低くなるの に対して，前庭では夜間の気温については水田と同様 に強風日の方が高いが，日中については弱風日と強風 
日の差が少ない。これは，強風日でも前庭は暖かい日 溜まりが出来ることを示している。

（4）このため,屋敷林に囲まれた前庭と外側の水田 との気温差は風速に関係すると考え，気象台の風速と の相関関係を調べたところばらつきが大きく，有意な 相関が認められなかった。

（5）次に典型的な晴天日を対象に気温の微変動を 調べた。60 分移動平均值に対する 10 分毎の気温の偏 差を見ると，日中前庭では水田に比べ 2 倍程度大きく， 夜間については同程度であった。風速の記録を見ると， 夜間から午前中にかけて前庭は水田より風速が小さい が，正午頃から夕方にかけては前庭の方が風速が大き くなった。冬季とはいえ海風の進入があり，これに対 して屋敷林の前庭は風上，水田は風下となり，冬の季 節風とは位置関係が逆転することがこのような結果を
もたらしたと考えられる。

（6）しかし,夕方から夜にかけて前庭の風速が比較 的大きいまま継続しているにも関わらず前庭の気温変 動は縮小することから，前庭の気温変動の増大は気温 上昇にともなう不安定化も原因と考えられる。前庭の 2 地点に打ける気温差と前庭の風速を見ると, 風速が 弱まると気温差が急速に桩大し，その直後に風速が急 に強まって気温差が解消することが分かった。この繰 り返しに，約 2 時間の周期性が読み取れる。

（7）連続的に晴天となった 2 月 15 日〜22 日につ いて，気温変動の周期性を見るため，フーリエ解析を 加えそのパワースペクトル分布を見ると， 24 時間，12 時間， 10 時間， 8 時間， 6 時間，210 分，140 分等の周 期が認められた。なお，水田の気温については 6 時間 周期より短いものは明瞭でなかった。

\section{仙台市海岸部における現存屋敷林}

仙台平野は屋敷林分布の上から全国的にみても中心 地の一つであるが，屋敷林の伝統的な機能が生活様式 の変化で存在意義を失いつつあり, 同時に仙台都市圏 の拡大にともなう近年の開発が著しく，その数が年々 減少していると思われる。そこで，仙台市の市街地に 比較的近い海岸の農村部において，現在の屋敷林分布 を把握することを目的として全戸調査を行った。

対象地域は仙台市若林区の東部で，行政メッシュの 3 次コードで 13 メッシュ分に当たる。このうち 3 メッ シュについては海岸砂防林のみで人家がなかった。調 査にあたり，前もって住宅地図で全ての住宅について 住所と世帯主を確認して調査表を作成しておき，現地 では屋敷林の有無の確認，屋敷林があった場合はその 規模(長さ，幅，高さ，密度)，構成している樹木種を 読み取って記録し，写真を撮った。持ち帰った資料は 原簿を作成するとともに，パーソナルコンピュータに 入力してデータベース化した。

典型的な屋敷林の例として, 名取市高柳の $\mathrm{T}$ 氏宅に おいて全樹木の位置と種類，胸高直径を計測した。そ れによれば，この屋敷林には 15 種 278 本の樹木があ り，その内最も多いのがスギの 146 本，以下ヒノキ 38 本，シロダモ 29 本，ハンノキ 20 本がつづき，クリ(9 本), ウメ (8 本), カキノキ(本) などの果樹も見られ た。ただしヒノキは明らかに近年の植樹で、樹齢が若 く生け垣の形に 1 列に密植され,他の樹木とは異なる。

\section{二瓶由子。佐藤裕子。菊地 立（東北学院大）}

したがって，この屋敷林は過半数を占めるスギを主体 とする樹種構成であるが，そのスギは胸高直径でみる と $20 \mathrm{~cm}$ 以下のものが 82 本で全体として若い。一方 ハンノキは本数は少ないながら若いものから直径 56 $\mathrm{cm}$ のものまでまんべんなく存在した。T 氏によれば, この屋敷林は約 100 年前にほとんど切り倒して消失 し，その後再生されたものということである。

屋敷林の分布調查から次のような結果が得られた。

（1）調査範囲に 350 戸の住宅があり，このうち 196 戸で屋敷林の存在が認められた。

(2) 行政 3 次メッシュでみると, 37 及び 46 のメッ シュで 32 戸に屋敷林があり, 最も多かった。しかし， 37 メッシュでは規模の大きな屋敷林は 9 戸に過ぎず, 46 メッシュの 17 戸とは差があった。このほか規模の 大きな屋敷林の割合が高いのは $25,35,45,56$ メッ シュなどで,海岸に近いメッシュではやや少なかった。

（3）屋敷林を構成する樹木の種類では，全体で 48 種認められ，このうちスギが 141 戸，ヤダケが 113 戸， シロダモ 91 戸, ハンノキ 85 戸，マダケ 82 戸において 認められた。優占種となっている樹種でみると，スギ がトップで 77 戸，続いてヤダケ 24 戸，マダケとサワ ラが各 20 戸であった (表)。

（4）海岸に近い井土,中野等の集落では屋敷林を持 たない住宅が多い。また宅地が道に面する間口が狭く 奥行きが長い土地割となっており，これより内陸側の 
表 屋敷林にみられる樹種別出現戸数

\begin{tabular}{|c|c|c|c|c|c|}
\hline 樹木名 & 戸数 & 優占種の戸数 & 樹木名 & 戸数 & 優占種の戸数 \\
\hline スギ & 141 & 77 & クワ & 6 & \\
\hline ヤダケ & 113 & 24 & イチョウ & 5 & \\
\hline シロダモ & 91 & 4 & カイズカイブキ & 4 & 3 \\
\hline ハンノキ & 85 & 12 & ビワ & 3 & \\
\hline マダケ & 82 & 20 & イチジク & 3 & \\
\hline マサキ & 73 & 19 & イヌッゲ & 3 & \\
\hline サワラ & 59 & 20 & キンモクセイ & 2 & \\
\hline クロマツ & 58 & 6 & シラカシ & 2 & \\
\hline カキノキ & 41 & & ツタウルシ & 2 & \\
\hline ツバキ & 36 & & キリ & 2 & \\
\hline シュロ & 32 & & ツリバナ & 2 & \\
\hline アオキ & 26 & & グミ & 2 & \\
\hline カエデ類 & 26 & & ニワトコ & 1 & \\
\hline ヒノキ & 18 & 6 & ネムノキ & 1 & \\
\hline クリ & 15 & & アケビ & 1 & \\
\hline オニグルミ & 13 & & ウラジロガシ & 1 & \\
\hline ケヤキ & 12 & & サンショウ & 1 & \\
\hline カヤ & 11 & 1 & ユズ & 1 & \\
\hline ヒイラギ & 11 & & ムクゲ & 1 & \\
\hline ミズキ & 10 & & ウメ & 1 & \\
\hline コナラ & 9 & & ウド & 1 & \\
\hline ヤナギ & 9 & & ライラック & 1 & \\
\hline エノキ & 8 & & エゴノキ & 1 & \\
\hline サクラ類 & 7 & & ノイバラ & 1 & \\
\hline イヌシデ & 6 & & モズ & 1 & \\
\hline
\end{tabular}

集落とは異なった構造であることが推察される。

\section{南蔵王南西麓周辺の河川（横川水系）の水質特性}

$\begin{array}{lll} & \text { 清 } & \text { 野 茂（宮城県保健環境センター） } \\ \text { はじめに } & \text { 方 法 }\end{array}$

宮城・山形両県にまたがる蔵王連峰は，蔵王火山と して，「活動的火山及び潜在的爆発活動を有する火山」 (気象庁)に分類されている。その中で, 南蔵王火山に 区分され，その南西山麓に位置する横川水系の水質調 查を実施したので報告する。

横川水系は, 宮城県の最南西部の七ケ宿町にあり, 標 高 1,600 1,800 m の南蔵王火山群に発源し, 白石川と 合流後，七ケ宿夕゙ム貯水池に流入する河川延長約 16 $\mathrm{km}$, 流域面積約 $50 \mathrm{~m}^{2}$ で, 20 余りの支川を有する河川 である。

本調査は, 1995 年 7 月 $25 \cdot 26$ 日に行ない, 調查地点 は 27 力所 (図参照)。水質調査項目は, $\mathrm{pH}$ 等の一般項 目, BOD 等污濁成分, 栄養塩, 無機塩, 重金属等 31 成 分, 現地にて流量測定を実施した。分析方法は概ねJIS K 0102 に準拠した。調查前 1 週間は $10 \mathrm{~mm}$ 以上の降 水量がなく, 調査時の水質は基底流出水質であった。 結 果

1）横川水系（全地点）の水質は, $\mathrm{pH}$ が $7.2 \sim 7.6$, 污濁成分・栄養塩・無機塩は, 東北・日本の河川水質 ${ }^{11}$ に比較すると低いものの, $\mathrm{Mg}$ 濃度は $9.9 \mathrm{mg} / \ell$ と高 


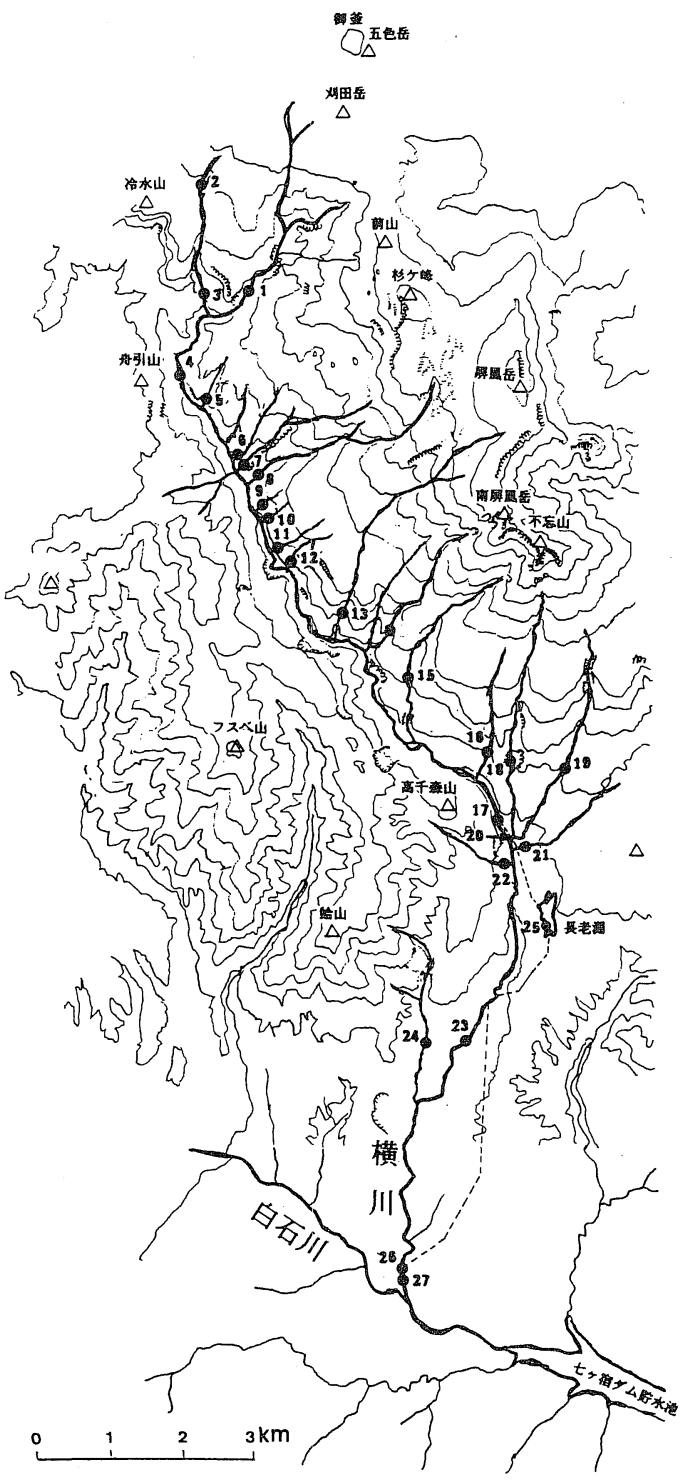

図
W。

2) $\mathrm{Mg}$ 濃度は，横川左岸 19 支川中最高 $15.8 \mathrm{mg} / \ell$ (地点番号 20 , 以下同様) で $10 \mathrm{mg} / \ell$ 以上が 4 支川測 定された。

3）左岸 19 支川でみると， $\mathrm{Ca}+\mathrm{Mg}$ (当量濃度）と アルカリ度の間には正相関 $(r=0.975)$ があり，炭酸等 を含む水と地質の反応によって $\mathrm{Ca}, \mathrm{Mg}$ が河川に溶出 している。

4）人為的活動がみられる支川は 21 のみで，T-N/ $\mathrm{T}-\mathrm{P}$ が $8.7, \mathrm{NH}_{4}-\mathrm{N}$ が $0.031 \mathrm{mg} / \ell$ で，最も高い濃度 であった。この他に，森林伐採による影響(14)，地質 由来 (19) の要因による特異な水質の支川がみられた。

5）舟引橋（4）と発電所取水口（17）の間約 $8 \mathrm{~km}$ での左岸 12 支川中 7 支川の水質成分流送負荷合計量 をみると，横川本川（27）に対する寄与割合いは，污 濁成分・栄養塩 7 52\%, 無機塩 39 69\%, $\mathrm{SO}_{4}$ と $\mathrm{SiO}_{2}$ 64〜68\%であった。

\section{引用文献}

1）半谷高久.菅原 健 (1964)：地球化学入門. 丸善.

\section{衛星リモートセンシングで把握した東北地方の植生改变状況}

\section{小荒井＼cjkstart衛（環境庁）}

昭和 48 年度よりおおむね 5 年毎に実施されている 自然環境保全基礎調查「植生調査」では，第 3 回調査 までに全国の 5 万分 1 現存植生図 1293 面が整備され ている。平成元年から実施された第 4 回調查では, 衛 星りモートセンシング技術を活用して植生改変地を抽
出し, 現存植生図の修正を行った。本発表では東北地 方を中心にその概要を紹介する。

1. 第 4 回調査の手法

2 時期のランドサットデータを重ね合わせ, 経年変 化画像を作成した(旧画像：1979 年〜1984 年,新画像： 
1986 年～1990 年)。経年変化画像上では伐採，造成な どにより植物量が減少したところが赤く発色し，逆に 遷移や植林地の生長等により植物量が増加してところ が青く発色している。今回の調査では, 植物量が減少 して赤く発色した部分を植生改変地として抽出し, 都 道府県委託調査により現地又は資料確認調査を行い, 最終的に確認された植生改変地を現存植生図上にオー バレイ表示し， 5 万分 1 植生改変図を作成した。

植生調査のとりまとめは, 植生改変図を基に小円選 択法により作成した「植生現況 3 次メッシュファイル」 と, 現存植生図上にオーバレイ表示された植生改変地 のポリゴンデータを集計した「改変地解析用ファイル」 の 2 つのファイルを使って解析を行った。

\section{2. 植生の状況}

植生自然度別に第 3 回と第 4 回の 3 次メッシュの出 現頻度を比較すると, 二次林, 自然林の減少が大きく, 植林地, 市街地 - 造成地等, 背の低い二次草原の増加 が大きい。日本は緑被地が $92.5 \%$, 森林が $67.0 \%$ と世 界的に見て緑の比率が高い国であるが，自然性の高い 植生が減少しており, 自然の保全や回復の視点からは 必ずしも良好な状態となっていない。

東北地方の約半分にあたる $48.0 \%$ が，植林地・耕作 地植生である。自然植生の大半を占めるブナクラス域 自然植生は $12.4 \%$ を残す程度で, 下北半島, 白神山地, 十和田湖, 八甲田山, 八幡平, 森吉山, 栗駒山地, 船 形山, 月山, 朝日岳, 飯豊山地, 裏磐梯などにまとまっ て分布するが，その分布域は限定されている。都道府 県別に見ると，自然植生の構成比は山形県が $20 \%$ 以 上，その他の県が $10 \%$ 以上と全国的に見て大きい。森 林植生は岩手県, 秋田県, 山形県が $70 \%$ 以上, 福島県, 青森県，宮城県が $60 \%$ 以上である。

3. 植生の改変状況

全国の植生改変地の面積を植生自然度別に見ると, 二次林, 植林地, 自然林の順に改変地面積が大きい。改
変地率では,二次草原と二次林が高い值を示している。 地方別に植生改変地の面積を見てみると，東北地方で の改变地面積が大きく, 約 112,000 ha である。次いで, 中部地方, 関東地方, 北海道の順で 60,000 ha を越える 改変が見られる。九州地方，中国地方，近畿地方では 約 40,000 ha の改変が見られる。

東北地方の改変地面積に占める植生自然度別の割合 を見てみると, 二次林が $44.0 \%$, 植林地が $24.4 \%$ と大 きい。自然林の改変地は, 青森, 岩手, 秋田の各県で 2,000 ha を越え，宮城，福島の両県で 1,500 ha を越え る。改変地に占める自然林の割合は, 宮城県で $30 \%$ を 越光, 青森, 山形，秋田の各県で $10 \%$ を越光る。改変 地に占める二次林の割合が高く, 福島 $60.9 \%$, 山形 $59.5 \%$ ，秋田 $46.1 \%$ である。

植生自然度別の改変前後の推移を東北地方について 見てみると，自然林では植林地，背の低い二次草原に 推移したものが多く,二次林では背の低い二次草原, 農 耕地，植林地に推移したものが多い。自然林では伐採 されて伐跡群落か植林地化にされるものが多いのに対 し, 二次林ではこの他に農耕地等への土地利用転換の 割合が高い。

ブナ林の改変地は, 東北地方と中部地方で多く, 秋 田, 宮城, 福島, 青森で 1,500 ha を越える。ミズナラ・ シデ林の改変は東北地方から北陸地方にかけて多く, 福島, 秋田, 岩手では 6,000 ha を越える。コナラ林の 改変は東北地方の太平洋側から北関東をへて近畿地方 の日本海側から中国地方にかけて多く見られる。岩手 の約 9,900 ha が全国で最も大きく, 福島が約 3,400 ha, 宮城が約 2,000 ha である。アカマツ林・クロマツ林の 改変は, 東北地方の太平洋側, 北関東, 近畿地方, 中 国地方に多く見られる。岩手の約 6,900 ha が全国で最 も大きく, 福島県が約 3,500 ha, 青森が約 1,600 ha, 秋 田が約 1,100 ha である。

\section{三国山地平標山に分布する埋没黒泥・泥炭層の ${ }^{14} \mathrm{C}$ 年代と炎れに介在するテフラの給源}

\section{佐々木明彦（東北大・院）・苅谷愛彦（地質調査所）}

三国山地平標山の埋没黒泥・泥炭層の生成開始期は かつて約 $3,000 \sim 2,400{ }^{14} \mathrm{C}$ 年前とされていた（小泉ほ か, 1984 ; 地理評, 57)。一方, テフロクロノロジーに もとづき，それを完新世前半とする見解が最近出され (Kariya et al., 1996; Geogr. Rep. Tokyo Metropol. Univ., 31), 意見の一致をみない。そこで平標山で採取
した埋没黒泥・泥炭層の ${ }^{14} \mathrm{C}$ 年代を新たに測定した。こ れには小泉ほか（1984）が年代試料を得た地点とほぼ 同じ場所の同じ層準から得た試料も含まれる。この結 果，時間指標テフラ層との関係からみて受け入れがた い若い年代が得られた（図)。慎重な試料採取とユー ザー前処理を行ったにもかかわらず，なぜ全ての試料 

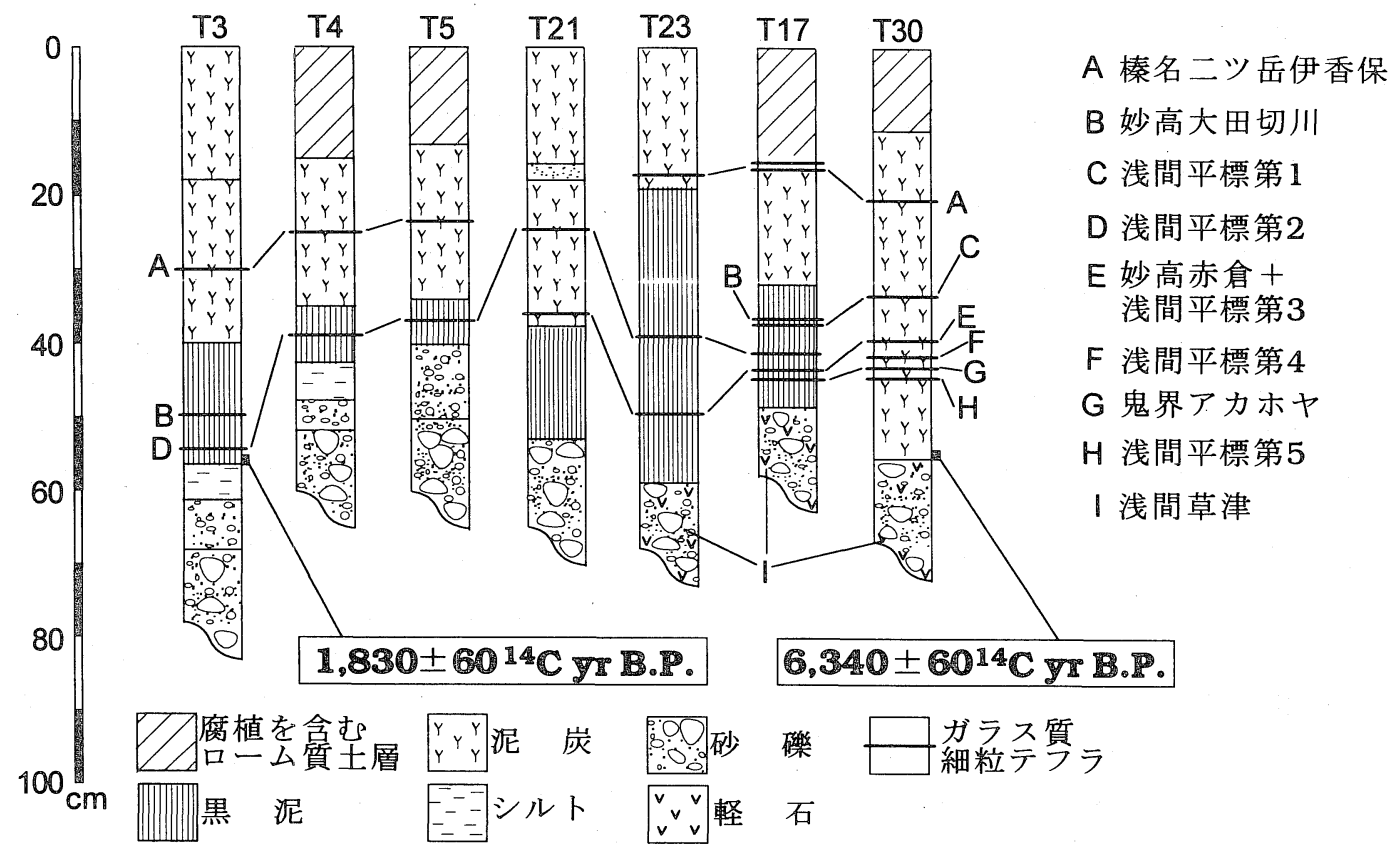

図 平標山の代表的な試坑断面（試坑位置は Kariya et al., 1996 を参照）

の年代が妥当なものでなかったのかは明らかでない。 しかし今回の結果は，土壤の ${ }^{14} \mathrm{C}$ 年代が何らかの時間 指標を用いたクロス・チェックを必要としていること を改めて示したといえる。

これとは別に，平標山の埋没黒泥・泥炭層に介在す る完新世テフラ群のうち, Kariya et al. (1996) と 佐々木ほか（印刷中；第四紀重要露頭集）が $\mathrm{My}-\mathrm{A}+$ As-T3 と称したテフラ中の火山ガラスと斑晶鉱物の 屈折率を再測定した。彼らは，このテフラが妙高赤倉 テフラと完新世浅間火山系テフラからなるとしたが, さらに詳しい岩石記載的特徵の把握が求められていた ためである。この結果，火山ガラスの屈折率は $n=1$. 496-1.499，1.509-1.514に集中することが明らかにな
り，本テフラが妙高赤倉テフラ $\left(5,800{ }^{14} \mathrm{C}\right.$ 年前 $)$ と完 新世浅間火山系テフラの混交物であることが再確認さ れた。こうした特徴は尾瀬ケ原湿原堆積物中のテフラ $\mathrm{X}$ 上部・下部層のそれ（新井，1980；科研費総研報告 書）に一致することから， $\mathrm{My}-\mathrm{A}+\mathrm{As}^{-} \mathrm{T} 3$ とテフラ $\mathrm{x}$ は同一であることが確実となった。平標山や尾瀬ケ原 に打けるこれらのテフラの産状からみて，浅間・妙高 両火山は完新世中期にほぼ同時（浅間火山が先行）に 噴火した可能性がある。 $\mathrm{My}-\mathrm{A}+\mathrm{As}-\mathrm{T} 3$ (テフラ x) の 岩石記載的特徵は特異なので，このテフラは三国・越 後山地とその周辺における高山土壤や湿原堆積物の編 年に今後役だつと考えられる。

\section{広島県北部の山地地域にみられる完新世初頭の年代を示す化石崩壊地形}

\section{吉 木 岳 哉 (東北大。院)}

斜面には，等高線が凹型を呈す通常の谷地形の他に， 堆積物で充填されていて地表形態には現れない，基盤 岩に刻まれた谷地形も存在する。また，両者の中間と して, 堆積物の厚い浅い凹みの谷地形もみられる。こ れらは何れも，斜面を開析する崩壊やガリ一侵食など
の線的な侵食作用によって基盤が削られた結果として 形成された地形であり, 最後の開析作用の発生以降の 埋積の進行具合により上記のような差異が生じてい る。発表者は, 古い時期の開析作用により形成され, 現 在は堆積物下に埋没している基盤の山みを化石崩壊地 
形と呼び,多くの堆積物基底の年代が約 25,000 年前前 後に集中することを，栃木県喜連川丘陵と広島県北部 の中国山地について既に報告している。今回は，これ に類似した化石崩壊地形の埋積開始時期が完新世初頭 の約 9,000 年前にも集中することを報告した。

化石崩壞地形は後氷期開析前線と呼ばれる遷急線よ り上方の斜面に位置し，それは上部谷壁斜面であるこ とが多い。そして，完新世初頭の化石崩壊地形に比べ, 約 25,000 年前前後のものの方が相対的に斜面上部に 認められるようである。また，完新世の化石崩壊地形 堆積物は黒色土や暗色のロームをマトリクスとするこ とが多く,約 25,000 年前前後のものとは堆積物の色調 が異なる。このような完新世の化石崩壊地形の堆積物 基底付近から, 3 つの埋没土㗧の ${ }^{14} \mathrm{C}$ 年代值を得た。そ れらは，約 8,400〜約 9,000 年前(TH-1828, 1829, 1830 ; 暫定値)と，かなり近い年代を示した。また，化 石崩壊地形堆積物中に約 16,000 年前の三瓶浮布軽石 を挟まないこと,さらに, 約 6,300 年前のアカホヤ火 山灰起源の褐色のバブルウォール型火山ガラスが少な くとも堆積物基底付近には認められないことは， ${ }^{14} \mathrm{C}$ 年代值と調和的である。

この報告以前にも，完新世初頭に形成された化石崩 壊地形が紀伊山地や松本盆地西縁の山地，筑波山周辺 で認められることを吉永（1991，地理予）が報告して
おり，広島県北部の山地で得られた結果は広い地域に 共通する現象であると考えられる。化石崩壊地形とは， 過去に開析作用が起こった地点で，堆積物基底によっ て示される時期以降，開析が行なわれていないことを 意味する。そして, 遠く離れた地域間で化石崩壊地形 基底の時期が一致することは，その原因が広い範囲に ほぼ同時に影響を及す気候変化であったことを示唆す る。その気候変化とは，豪雨時に斜面の開析作用が及 ぶ上限の位置が下方へ移動する現象を引き起こすもの であり, 豪雨時の降水強度が小さくなるような気候変 化であったと予想される。したがって，化石崩壊地形 の位置，そしてその存在自体から，完新世初頭の約 9,000 年前前後は完新世の期間で最も降水強度が大き く, 斜面は活発に開析されていたと推定される。また, 約 25,000 年前前後は完新世初頭よりもさらに開析が 活発であったと推定される。一方, 完新世における開 析作用の上限を示す地形線として認識されることの多 い後水期開析前線の位置は, 完新世初頭の化石崩壊地 形，あるいは完新世に何度も崩壊を繰り返していると 考えられる谷型斜面の位置と比べて，明らかに下方に 位置する。つまり，後氷期開析前線は必ずしも崩壊や ガリー侵食などの開析作用の上限を示しておらず，む しろ現在の河床高度や水流の側刻の影響を受けている 開析作用の上限を示すと考えられる。

\section{トマムの $11^{\circ} \sim 17^{\circ}$ の山簏斜面の物質移動様式と斜面発達}

北海道，トマムにおける鵡川とポロカトマム川の合 流地点のすぐ南側に位置する標高約 $700 \mathrm{~m}$ の山地の 山麓部に, 斜面傾斜 $11^{\circ} \sim 17^{\circ}$ の山麓斜面が発達してい る。この山麓斜面の上方に山地を刻む傾斜約 $30^{\circ}$ の化 石化した侵食谷が連続する。また山麓斜面の下方（前 方）には河成段丘が分布する。この山麓斜面に形成さ れたいくつかの人工の法面に扔いて, 最終水期に降下 した火山灰が挟在する堆積物が観察されたので，その 層相の特徵や堆積勾配などから運搬営力の変化と斜面 発達について考察を試みた。

その結果，Spfa-1 および Kt-1（約 3 万数千年 B.P. $\sim 4$ 万年 B.P.) 降下以前の堆積物は厚さが $11 \mathrm{~m}$ 以上 あり，淘汰の悪い亜角礫〜亜円礫を主体としてマト リックスに砂をもっている。また碩の長軸方向は平均 方向への集中度が低い。さらに $17^{\circ}$ の勾配は粘着力を 考慮しなくてよい物質が低速の岩屑流から高速の岩屑

\section{山 本 憲志郎 (筑波大)}

流 (土石流)に移行する境界である(伊勢屋ほか，1995） ことから，流動性の高い土石流によって運搬されたと 考えられる。またこれらの堆積物に, 深いガリ一痕跡 が認められないことから， $30^{\circ}$ の谷から緩斜面への岩 屑供給がかなり大きかった時期に堆積したと推定され る。すなわち緩斜面上に扔いて発生した土石流の先端 部が停止すると，その土石流流路を上流にむかって急 速に掃流状堆積物が埋積していく（水山，1988）よう な状態であったと思われる。

山麓斜面は広く開析されているが，部分的に残され た傾斜 $13^{\circ}$ の尾根部では, Spfa- 1 および Kt -1 は岩屑 を殆ど含まないのに対し，En-a（約 1 万 8 千年 B.P. 〜 万 5 千年 B.P.) は亜角礫を多量に含んでいる。この 礫のファブリックは計測礫の長軸の平均方向と斜面の 最大傾斜方向との偏差が小さく, 平均方向への集中度 も高いことから周水河環境下においておもにソリフラ 
クションによって運搬されたと考えられる。このこと から, Spfa-1 Kt-1 期には岩屑の生産が減少したが, En-a 期には再び岩屑生産が増大したと推定される。

En-a 降下期以降の土石流堆積物は, 厚さ約 $6 \mathrm{~m}$ で 著しく開析されている。これは En-a 降下期以降しば らくの後に， $30^{\circ}$ の傾斜をもつ谷からの岩屑の供給が 減少し，山麓斜面の岩屑の貯留量が減ったために，土 石流が発生してもその流路が掃流状堆積物によって埋 積されなくなり，次第に流路が固定化して斜面を侵食 した（水山，1988）ことを示唆している。

調查地域には，鴻川に沿って 3 面の河成段丘が認め られる。最高位にある段丘は, その堆積物中に再堆積 した En-a が挟在すること，またその下位の腐植質シ ルトのC-14 年代が $25,440 \pm 290$ y.B.P., $17,030 \pm 280$ y.B.P. であったことから，En-a 降下期〜Ta-d 降下期
(約 9 千年 B.P.) 以前に段丘化したとされる柳田 （1991）の MwII あるいはI面に相当すると考えられ る。さらに中位の段丘はその連続性から, Ta-d 降下直 前に段丘化したとされる MwIII 面に相当するものと 考えられる。これらの段丘は，土石流堆積物に被覆さ れていないことから，山麓斜面上では少なくとも完新 世において顕著な斜面物質移動が無かったと考えられ る。このことから En-a 降下以降における山麓斜面上 の物質の鵡川への運搬（＝侵食）は，完新世に入る以 前に終了していたと推定される。

本調查地域の山麓斜面は，その殆どが土石流および 掃流状堆積物の集合体であり，ソリフラクション堆積

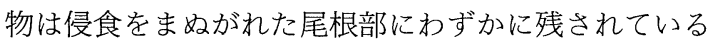
のみである。また岩屑供給の相対量の増減が，斜面形 の決定に大きく寄与していると思われる。

\section{上高地，梓川河床における 1995 年 7 月上旬の豪雨による地形変化（速報）}

\section{岩船昌起（東北大・院）・岩田修二 (都立大) ・池田明彦（品川区役所）・川口裕輔（東北大・院）} 加藤仁美・山下浩樹 (東北大・学) ・福井幸太郎・香山雅純・前田 豊（東京学芸大・学）

上高地自然史研究会では, 1993 年から徳沢下流約 1 $\mathrm{km}$ の梓川河床および河辺林を調査している。1995 年 7 月上旬の豪雨によって, 梓川の水位が上昇し,この調 査地域左岸の河辺林が登山道沿いに冠水した。演者の 一人・岩船は, この時現地に帯在し，好運にもこれに 関連する河床変化の一端を観察することができた。本 発表では，地形変化後の 8 月の共同で行われた河床で の測量結果も加味し，7月上旬の豪雨による地形変化 を日単位の時間スケールで整理する。そして，1993 年 7 月 14 日の洪水での地形変化との比較から, 上高地梓 川の砂碩運搬プロセスについても若干考察する。

1995 年 7 月前半には，主として，3 日，8 日，11〜 12 日をそれぞれピークとする 3 回の大雨があった。上高 地での日降水量では，3 日に $117 \mathrm{~mm}, 8$ 日に $132 \mathrm{~mm}$, 11 日と 12 日に $92 \mathrm{~mm}$ と $108 \mathrm{~mm}$ がそれぞれ記録さ れている(日本気象協会長野センター，1995)。現在観 察は，3 回の大雨の後，7月 6 日，11日，8月 5 日にそ れぞれ行われた。

徳沢約 $1 \mathrm{~km}$ 下流の登山道の冠水は, 7 月 3 日を中心 とした1〜6日にかけての大雨によって既に生じてい た。7月 6 日の現地観察から外挿すると，3日の降水 ピーク直後にも上流からの土砂供給もほとんどなく, 梓川本流での地形変化もそれほど激しくなかった。ま た，8日の洪水時には，上流からの土砂供給もはるかに
多く，河床では掃流層が形成されていた。さらに，す でに水位が上昇し，土砂移動が生じているところでも たらされた 11 日夜半からの大雨によって，11〜12 日 には 8 日以上の地形変化が生じたと考えられる。一方, 登山道では, 8 日にはそれほど冠水せず, 土砂の流入は ほとんどなかった。7日に重機による緊急的な流路変 更が行われていたためと思われるが，11〜12 日には， さらに水位が上昇したために, 再び冠水した。

この登山道の冠水は, 基本的に日降水量 $100 \mathrm{~mm}$ を 超える大雨直後に生じている。しかし，本流での地形 変化の少ない 3 日に既に生じていること, 緊急的な流 路変更工事を施した後にも再び冠水していることか ら，以前の何回もの洪水による堆積の積み重ねによっ て，ここでは，河辺林内へ流入しやすい下地が形成さ れていたと考えられる。そして, この素因が今回の冠 水では大きく関与している。つまり, $10^{1}$ 年オーダー程 度のより長期的な視点からみると, ここは河辺林内へ 流路が変動する転換期にあると見なせる。

徳沢下流約 $1 \mathrm{~km}$ の梓川河床で, 1995 年 8 月にレべ ル測量を行った。砂砂堆 1 つを対象とした平板測量で は侵食傾向であったが, 河床を横断する測線測量では， 侵食・堆積の収支がほぼ釣り合っていた。従って，7 月 8 日と $11 \sim 12$ 日の 2 回の大雨による洪水によって, こ こでは, 砂碟堆の 1 つの位置が変わる程度の空間的ス 
ケールで部分的な侵食・堆積が生じたと見なせる。ま た, 河床構成物質は, 河床の中央部から左岸の部分で, 粒径の最大值と平均值がともに小さくなった。これは, 槍沢から供給された土砂に関連する砂などが流心から 外れた流速の遅くなる部分に堆積したためと考えられ る。

この測量結果と前述の観測結果から, 7 月 8 日以降 には, 横尾から徳沢下流約 $1 \mathrm{~km}$ までの河床では, 次の ような地形変化が生じたと思われる。まず，横尾の合 流付近では, 横尾谷からの土砂供給はほとんどなく, 主 として槍沢から供給された土砂の移動扔よび特に巨大 な砂を中心に堆積が生じた。下流では徐久に堆積が卓 越し，新村橋付近までで，槍沢からの供給された礫の 直接的な堆積がほぼ完了した。德沢付近から下流約 1 $\mathrm{km}$ 付近の河床では, 槍沢からの直接的な碟供給の影 響がそれほどなく, 河床砂砂の再移動による侵食・堆 積が部分的に生じた。砂の堆積が多いことから, 河床 にもともとあった礫の間に砂が入り込み, 礫の再移動 が生じるといった, 水理実験で確認されているプロセ スが生じていた可能性がある。

一方, 1993 年 7 月 14 日を中心に, 3 日間で $285 \mathrm{~mm}$, 2 日間で $215 \mathrm{~mm}$ を記録した大雨があり, 横尾谷では 地下水位の上昇にともなう河床の侵食によって, 梓川 本流に推定で $1,000 \mathrm{~m}^{3}$ 程度の砂礫を供給した。しかし
ながら,この時は, 槍沢からの土砂供給はほとんどな く, 1995 年に比べて本流への土砂供給量ははるかに少 なかった。徳沢下流の河床では, この洪水前後の地形 変化がそれほどなかったことが地形学図から確かめら れている。

1993 年と 1995 年とを比較すると, 降水パターンが 異なるが, 1995 年が総降水量としては倍近く多いと見 なせる。また, 1993 年には扇状地的な河床からの若干 の砂礫が, 1995 年には槍沢沿いの斜面崩壊などによっ て大量の土砂がそれぞれ供給された。そして, 本流で の地形変化は, 1993 年よりも 1995 年の方が激しかっ たことから，両者の地形変化は流域単位で異なるもの であったことが解る。特に, 本流での地形変化は, 洪 水による流量の多さだけでなく, 上流からの土砂供給 の量や質によって大きく変容することが示唆される。 従って, 徳沢付近での地形変化のメカニズムを解明す るには，遷急線より下位の斜面を含めた上流域での地 形変化にも着目する必要がある。しかしながら, 各地 形単位やそれらの流域での位置によって, 地形変化が 生じるメカニズム（水文過程）がそれぞれの場所で異 なることから,ょり精度の高い観察と, 流量などにつ いての継続的・定量的なモニタリングを行う必要があ る。

\section{三態様の自然堤防調査の相違と相似}

籠 瀬 良 明（黒部川扇状地研究所）

会場では天塩川雄信内, 幾春別川, 雄物川左手子, 最 上川左沢一宮宿, 武蔵野台地などから選んだ現成・段 丘上・ローム層下埋没の三態様の自然堤防を 13 枚の OHP で述べたのを三点にしぼる。(1) 幾春別川岩見 沢地区の自然堤防には $\mathrm{K}-\mathrm{K}^{\prime}$ (同市 $1: 2,500$ 等高線図 と北海道開発局河川横断図）の特色と，1975 年溢水以 来洪水位が約 $3 \mathrm{~m}$ 低下し, 自然堤防頂が段丘上自然堤 防に変質したという特色がある。それはダムによる流 量カットと河道改修の成果で, 自然現象ではない。(2) 1975 年 A・B・C 三点を四倍に拡大し, 自然堤防と推 察した。しかし A 点と同じ位置に明記の土塁(駒垣)が 気になり，20 年後の去る日不自由な足で家族に助けら れて土を踏み， $590 \mathrm{~m}$ の等高線は東西方向の自然堤防 頂線，土塁はそこに重なることが確認できた。土塁が $\mathrm{A}$ 点以東へ伸びていないのは, 阿武隈川岸が $55 \mathrm{~m}$ も
の急崖ゆえに馬の逃亡がないとの予測は，土塁べりの 並木家と村役場で確かめえた。C 点の自然堤防森林の 厚い腐植層からの土を東京で洗った結果, 流水性の砂 と分った。B-C 自然堤防は河床から約 $60 \mathrm{~m}$ の高所だ が，腹ばって南北断面を伺うと幾春別川の最新の L$\mathrm{K}-\mathrm{K}^{\prime}$ 面と酷似して, 見事な非対称型である。個々の自 然堤防間の相似と相違は時間だけでなく, 形成条件の 違いにもよることを思わせる。(3) 武蔵野面の d-d'自 然堤防は地表ではなく，8～9 m のローム層 (L) 下で, 局所的な粘土層 $n$ を厚く被う古多摩川扇状地（武蔵野 礫層 $\mathrm{M}$ ) 面である。地質断面図では近接の $\mathrm{d}-\mathrm{d}^{\prime}$ 間の ロームは等厚だから,埋没自然堤防の緩斜面 $\mathrm{d}^{-} \mathrm{d}^{\prime}$ は地 表面すなわち右上端の等高線図にほほ一致する。従っ てこの等高線図は, 厚いローム層で保護されていた埋 没自然堤防の背面（緩斜面）形を知る鍵に使える。 

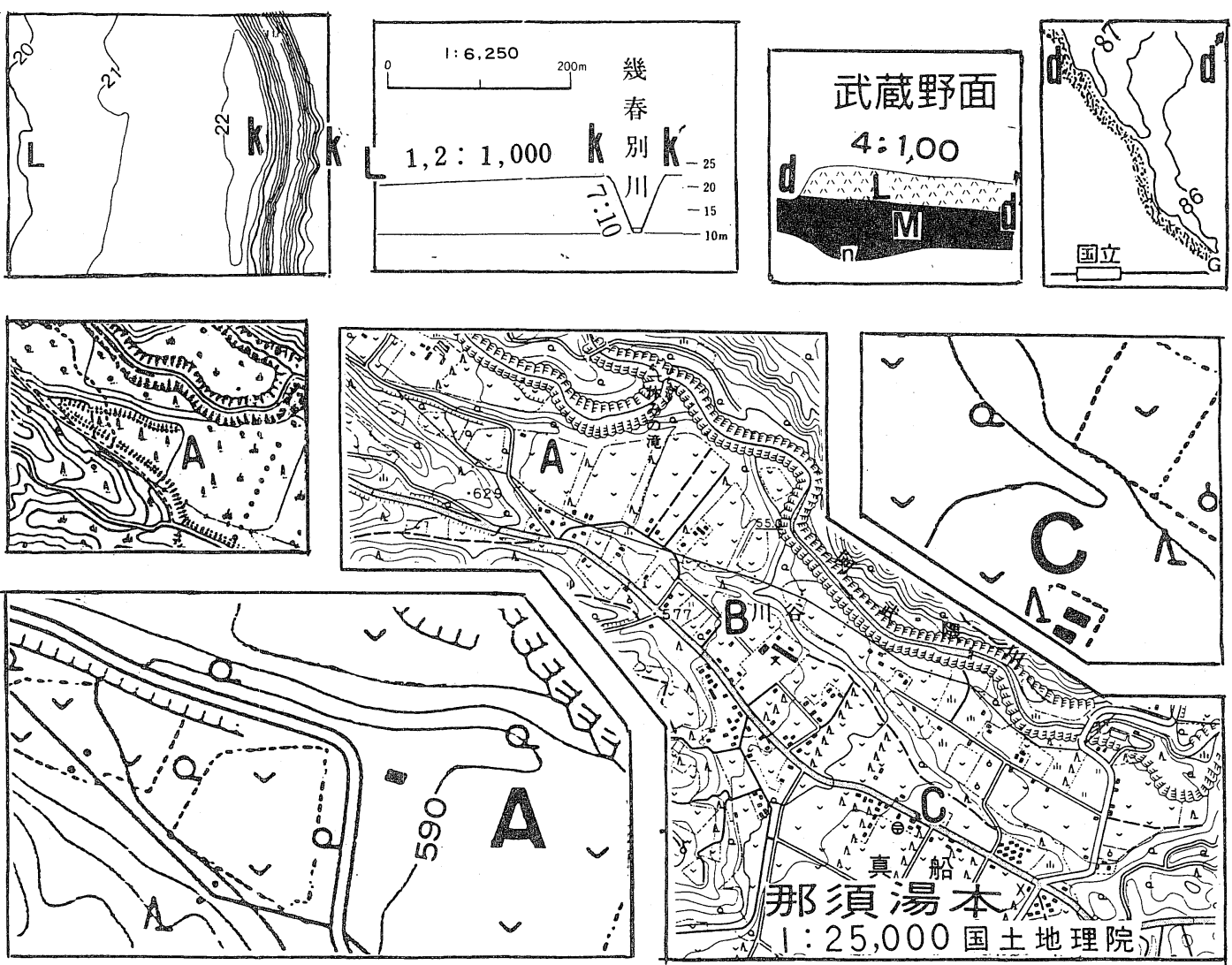

目

参考文献

籠瀬良明（1996）：JR 中央線以北国分寺崖線上縁口ー

么層下の帯状微高地。地図, Vol. 34, No. 1.

東北地方における果樹栽培地域の気候環境について

青山高義・長谷川典夫・柳瀬 訓（専修大）

果樹栽培地域は安藤(1962)が述べているように，特 定の産地に集団化する傾向が強いが，その理由として 人文的条件のほか気候条件や土壤条件あるいは地形条 件など自然的条件があげられている。特に，東北，中 部地方では集団化の傾向が強く, 弘前平野, 福島, 山 形，甲府，長野，松本などの盆地に集中しており，土 地利用上著しく傾斜地に多いという特色を持ってい る。本研究では東北地方を中心として, これらの果樹 栽培地域の気候環境を考察した。

\section{果樹栽培地域}

日本の果樹栽培地域の分布については, 安藤 (1962), 山本・内山(1985)なぞの研究がある。山本・内山 (1985) は果樹園密度とその標準偏差によって各果樹の分布パ ターンを示しているが，ここでは東北 6 県について市 町村毎の果樹園面積を対数正規化しその標準偏差に よって 5 つのタイプに分け，栽培面積が多い 3 タイプ の分布を求めた。対象とした果樹はリンゴ, ブドウ，モ モ，カキである。 
果樹ごとに分布が異なるのは当然であるが,リンゴ, ブドウ，モモなどの主要な栽培地域は重複し，津軽平 野, 山形・米沢盆地, 福島盆地などがこれらの果樹の 栽培地域となっている。これに加えて，馬淵川上流域， 横手盆地，岩手県の紫波，大迫町，一ノ関など北上川 流域と北上山地西麓などをあげることができる。カキ は庄内平野, 会津盆地, 山形盆地の西部など, ほかの 果樹よりも南に限られている。

\section{水文気候環境}

気象官署とアメダス観測地点における 1966-1982 年 の月平均気温と月降水量を用いて, 年々の気候的水収 支をソーンスウェイト法によって求めた。可能蒸発散 量は純放射の指標でもあり積算温度でもあるので温度 条件を示し, 水不足量は顕熱輸送の指標にもなる。こ れらの分布と果樹栽培地域の分布を比較すると, リン ゴ, ブドウ，モモの主要な栽培地域は, 可能蒸発散量
$650 \mathrm{~mm}$ 以上, 水不足量 $25 \mathrm{~mm}$ 以上の温暖乾燥地域に 対応している。これにたいして，カキは，水不足量が $10 \mathrm{~mm}$ 以下の湿潤な地域が主要な栽培地域となって いる。

可能蒸発散量と収量の関係

山形県の置賜, 村山, 最上, 庄内地方の各果樹の 10 アール当たりの収量 $(\mathrm{kg})$ と高畠, 山形, 新庄, 酒田 の可能蒸発散量の関係を求めた。横軸に可能蒸発散量 をとった散布図上で，可能蒸発散量が $700 \mathrm{~mm}$ 以下で は正の相関を，以上では負の相関を持つような上に凸 の放物線で示される関係を示す。可能蒸発散量 700 $\mathrm{mm}$ 以上で乾燥の影響が顕著になるものと思われる。

甲府, 長野, 松本, 諏訪盆地などにおいても, 主要 な果樹栽培地域はほぼ同椂の水文気候環境下に分布し ている。

\section{東頸城丘陵の地すべり地形と光の分布}

新潟県の東頸城丘陵の地すべり分布に関する調査研 究は, 地すべり等防止法の制定と関係し, 調查され, 1/ 5 万地形図上にプロットされた新潟県の内部資料をは じめ，建設省土木研究所新潟試験場が作成した $1 / 5$ 万 分布図, 磯崎（1977）の分布図などがある。前二者は 分布図のみであるが, 磯崎（1977）は能登半島から魚 沼丘陵に至る北陸地域を取りあげ，地質・地質構造と の関係を分析した

それらの成果は, 構成物質との関係では, 鮮新世〜更 新世魚沼層群 $(2.8 \%)$, 鮮新世扊爪層 $(10.4 \%)$, 西山 層 $(21.4 \%)$, 中新世椎谷・寺泊層 $(39.9 \%)$ などに多 く, 時代的に古い地層に多くなっている。地質構造と の関係では安塚背斜, 小田島背斜, 長倉背斜, 上船倉 背斜，小谷島背斜，儀明背斜，松之山ドーム，黒岩背 斜, 山中背斜, 片貝・直人背斜に多く,このほか須川 向斜，朴ノ木向斜に多くなっていることが判明してい る。しかし，磯崎（1977）が扱った資料は空中写真や 現地調査によって地すべり地形を判読して作成した資 料ではなく，分布図の内容から見て地すべり防止指定 区域を基図としたものと思われる。また，近年の著し い地球科学の発展に伴ない, この東頸城丘陵を含む北 部フォッサマグナ地域の地質構造上の考え方に新たな 視点が加わっている。

このような理由から，ここ数年北部フォッサマグナ

\section{古谷尊彦（千葉大）。渡辺慈明（ドリコ(株）}

地域の地すべりに関して，空中写真による地すべり地 形の判読と現地調査を行ってきた。ここではこれまで に得られた結果を示す。

東頸城丘陵の地すべり発生の背景となる地質構造 は, 相模トラフから系静線を通り, 日本海に至る大構 造の境界に隣接する。西に位置する姫川周辺では付加 帯と思われる中・古生層の地層が存在するが，東頸城 丘陵ではこれは存在せず，大構造の動きに支配される 活褟曲, 活断層の発達する地帯である。作成された地 すべり地形の分布図 ( $1 / 2.5$ 万原図) とこれら活褶曲, 活断層, 地質構成との関係は, 従来の成果の大筋を変 更することはないが，以下のような傾向が見られた。

地すべり地形は椎谷層・寺泊層・西山層などの泥質 岩, 泥岩・砂岩互層地带に多く, 泥質岩地带では一般 に規模が小さく，多発傾向にある。また，活䄍曲の軸 部に集中する傾向があり, 活褟曲の発達する椎谷層。 寺泊層の分布する安塚町・板倉町などに小規模多発し ている。松之山ドームでは凝灰岩の発達と関係し，規 模の大きい地すべりが集中する

起伏高度との関係では，小松原（1993）が示したよ うに，高度を増すと規模が大きくなる傾向があり，サ ギングを伴う頻度も高くなる。かつ硬質の岩層になる 傾向にあり，火山岩からなる米山では地すべりはほと んど存在しない。 


\section{高舘丘陵におけるプレ 1994 年崩壞の発生年代 \\ (Age of the Pre-1994 Regolith Slide in the Takadate Hills)}

\section{李穎・松林 武（東北大・院）・田村俊和（東北大）}

More than 1,000 regolith slides were induced by localized heavy rainfall which exceeded $80 \mathrm{~mm}$ per hour and attended $500 \mathrm{~mm}$ per day in September, 1994 in the Takadate Hills, south of Sendai. Most of the slides took place in valley heads and debris flowed down. Deposits as products of former slides were also found below the 1994 debris in some head hollows and adjacent bottomlands. In order to investigate the periodicity of regolith slides, radiocarbon dating was applied to the buried humic soil overlain directly by the deposits which indicated the pre-1994 slides. The samples were collected from two sections in the same valley: one is in the head hollow where 1994 slides also occurred, another is in the narrow bottomland about $130 \mathrm{~m}$ down stream the former section (Fig.). The buried humic soil in the head hollow section was dated as $350 \pm 30 \mathrm{BP}$ and that in the bottomland section $400 \pm$ $30 \mathrm{BP}$. The two dates are considered to be almost identical. Moreover, the bottomland section shows several thin debris flow deposits underlain by the relatively thick deposits which rest on the dated humic soil. The thin layers indicate the occurrence of several times of minor secondary slides of formerly slided material. On the other hand relatively big regolith slides which remove weathered bedrock were suggested to repeat at intervals of almost 350 to 400 years. Such slides contribute to enlarge head hollows backward.

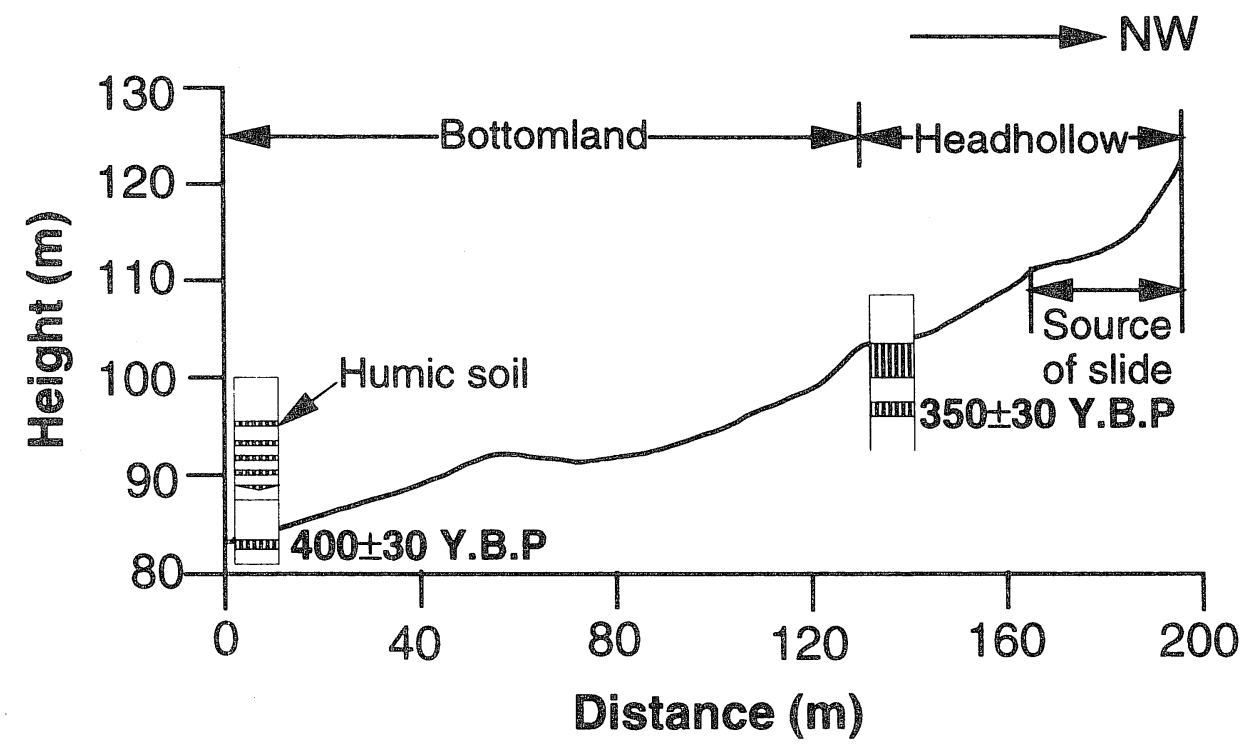

Fig. Cross section of the valley in the failure area in the Takadate Hills. 


\section{名取市高舘丘陵における 1994 年 9 月豪雨時の土砂生産量と流域地形特性}

1994 年 9 月に, 仙台市南方の名取市を中心として記 録的な集中豪雨が発生した。この豪雨のピーク時の雨 量は 1 時間に 80 ミリを越え,多いところで累積雨量は 500 ミリにも達した。この豪雨により, 平野部では河川 が氾濫し，農作物などに多くの被害をもたらした。一 方で，これらの河川の源流部である高舘丘陵では数多 くの斜面崩壊が発生し, 流域中に大量の土砂が堆壤し た。しかし，その土砂堆積量は流域によってかなりの ばらつきがあることが判明した。

そこで, 降水条件や地質条件といった斜面崩壊の発 生条件が同じと考えられる 2 流域で, 土砂の堆積量の 比較を行い, その差が生まれた原因について考察を 行った。

対象とした 2 つの流域は，増田川流域と川内沢川流 域で, 流域面積はそれぞれ約 $10 \mathrm{~km}^{2}$ と $7 \mathrm{~km}^{2}$ である。 土砂の堆積量は，災害復旧の資料などから，それぞれ 約 3 万 $\mathrm{m}^{3}$ と 5 万 $\mathrm{m}^{3}$ と推定され, 流域面積の小さい川 内沢川流域の方が多く土砂が堆積している。よって川 内沢川流域の方が土砂生産が活発に行われたことが予 測される。

空中写真判読により，土砂の生産源である斜面崩壊 の数を比較すると, その発生密度に流域による大きな 違いは見受けられない。よって斜面崩壊の個数の差は, 川内沢川流域の方で土砂の生産量が多いということの 説明にはならない。

斜面崩壊を，その発生場所で「谷頭崩壊」と，「渓岸 崩壊」に分類すると, 今回発生した斜面崩壊の大部分 が「谷頭崩壊」であることが判明した。そこで「谷頭 崩壊」の発生場所である 1 次谷の数との関係を調べる と, 流域によらずほぼ一定の割合で, 1 次谷の数に対し て「谷頭崩壊」が発生していることが判明した。しか し 1 次谷の密度も 2 つの流域の間で大きな差はなく, このことも川内沢川流域の方で土砂生産量が多いこと の説明にはならない。

そこで, 斜面崩壞 1 ケ所あたりの土砂生産量の見積

\section{馬場 俊 行（東北大・院）}

もりを行った。いくつかの崩壊地の現地調査により, 崩 壊の深さはほぼ一定で, 崩壊源の面積は, その幅によっ て決定されると考えることができた。そこで，全崩壊 数のおよそ1割の崩壊について, 空中写真からその崩 壊の幅を計測し，土砂生産量をそれぞれ計算した。そ の結果, 崩壊 1 ケ所あたりの土砂生産量は, 渓岸崩壊 については流域によって差がないのに対し，谷頭崩壊 については川内沢川流域で発生したものの方が 3 倍程 度も多いことが判明した。

この1ケ所あたりの土砂生産量の結果に, 崩壊の数 をかけあわせてそれぞれの流域の土砂総生産量を求め ると, 川内沢川流域の方が多くなり, 堆積物の量の傾 向と一致した。

土砂総生産量のうち, 渓岸崩壊によるものは僅かで あり，流域によって大差はなく，大部分は谷頭崩壊に よるものである。そしてその流域による土砂総生産量 の差は, 谷頭崩壊によって生産された土砂量の差に よって発生していることがわかる。つまり, 谷頭崩壞 1 ケ所あたりの土砂生産量が, 流域の土砂総生産量を 決定しているといえる。

この谷頭崩壞 1 ケ所あたりの土砂生産量の流域によ る違いを発生させている原因は, 崩壊の発生条件が同 じなので, 流域の地形特性の違いにあると考えられる。 対象の 2 流域は，隣合っているにも関わらず，流域の 形状はかなり異なっている。

しかし, 4 次流域単位で, 土砂生産量と様々な地形特 性との比較を行ったが, 現在の所, 土砂生産量に大き く関わる地形特性は見つかっていない。流域の水系密 度や起伏比，そして地質条件が，土砂生産量の上限を 規定する弱い関係が見られたが，2 流域の間に差を生 じさせた原因とはなりえていない。斜面崩壊という現 象が，どの程度のスケールでの地形特性に影響されて くるか，ということをはっきりさせるのが課題である といえる。 


\section{丘陵地小流域における植生と地形との対応関係}

高舘丘陵，川内沢川上流部を事例に

$$
\text { 松林武（東北大・院） }
$$

丘陵地における植生と地形との関係を調べた研究で は，植生をスタンド調查・ライン調查で求めた，いわ ば点・線データとして扱い，それが別々に区分された 微地形単位ごとにどのように異なっているかを議論し たものが多い。しかし，地形単位の分布と植生単位の 分布との一致・不一致を検討するためには，植生につ いても，地形と同様に固有の形・広がりを持つものと してとらえる必要がある。そこで今回は，相観により 植生を固有の形・広がりを持つものとして把握する「植 生パターン」という概念を考案し，仙台市街南方約 20 $\mathrm{km}$ に位置する高舘丘陵を流れる川内沢川の一つの三 次谷の集水域（面積約 $0.45 \mathrm{~km}^{2}$, 比高約 $180 \mathrm{~m}$ ）に扔い て，地形と植生パターン分布域とを比較した。

空中写真上で，樹冠の形状・樹冠の色・樹高の 3 つ の指標をもって，相観により均質と判断されるある程 度以上の面積を持つ植生の分布域とその境界を認定 し，現地調査でその分布域と構成樹種とを確認して，5
種類の植生パターンを認定した。また，空中写真判読 と現地調査から，傾斜変換線の分布を調心゙，地形区分 を行った。さらに，各植生パターン内にいくつかの試 坑を掘り，その土㙥断面形態から地表の安定度と土壌 水分条件を判断した。

各植生パターンは, それぞれ異なる構成樹種から成 り立っている。そして, その植生パターンの境界は, 傾 斜変換線と重なることが多い。これは例えば，コナラ が優占する植生パターン 2 が，地表の安定度が高く土 壌が比較的乾燥したところを立地条件とする様に，各 植生パターンは土猿断面形態により代表される固有の 立地条件を持ち,この土壌断面形態の特徵と広がりは, 微地形とよく対応するためと考えられる。結果として, 地形・土壤・植生は, カテナ的構造を持つ。

しかし，典型的な頂部斜面・上部谷壁斜面の土㗒水 分条件と地表の安定度とを立地条件とする植生（植生 パターン 1 と植生パターン 2) は, 必ずしも頂部斜面と
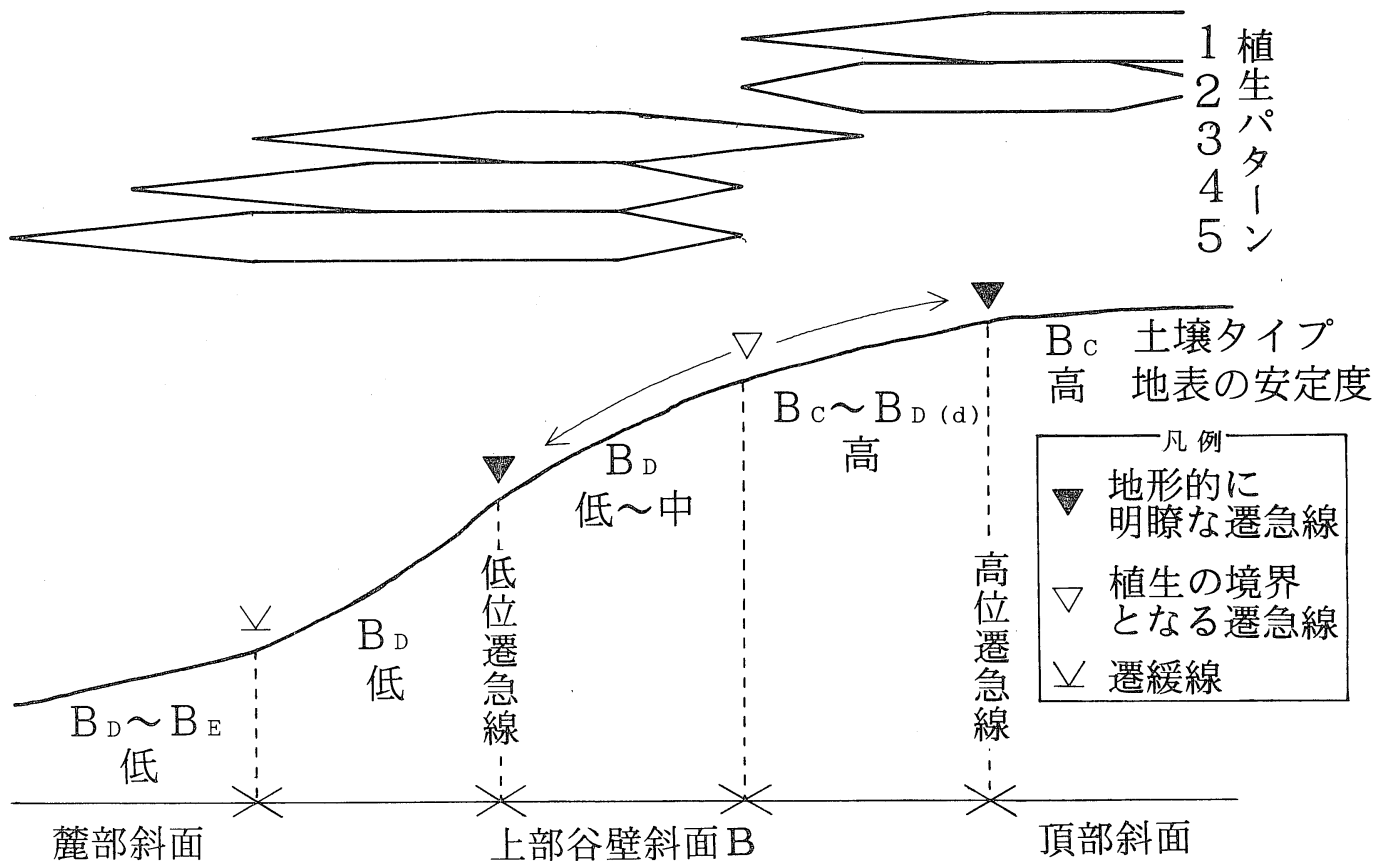

下部谷壁斜面

上部谷壁斜面 $\mathrm{A}$

図 高舘丘陵・川内沢川上流部における地形と植生パターンの対応 
上部谷壁斜面の全体に分布するわけではなく，上部谷 壁斜面上の地形的にそれほど明瞭ではない遷急線の下 部には分布しないことがある。これは，上部谷壁斜面
下部に位置するこの微地形単位 (上部谷壁斜面 B) が， 典型的な上部谷壁斜面（上部谷壁斜面 $\mathrm{A}$ ）よりも，地 形変化の活発な微地形単位であるためと考えられる。

\section{天童市ジャガラモガラ冷気湖の熱収支について}

ジャガラモガラ凹地は，天童市東方，奥羽山脈西斜 面中腹の大規模地すべりの地割れ凹地のひとつで高度 $550 \mathrm{~m}$ 前後にある。石英粗面岩であるため, 崩積層の岩 屑が大きく空隙が多いため，いわゆる累石型風穴が生 じている。周辺斜面は林地であるのに，凹地底は丈の 低い亜高山性の植物が分布していて，植生分布の逆転 現象となって抢り，風穴植物群落として天然記念物 （1995.3 県指定）となった。この凹地が冷気湖となる原 因として，風穴からの冷気によるという考え（安斎 徹，1943）と，放射冷却による冷気が滞留するという 考え（梅本，1994）とがある。梅本 (季刊地理 46-3) は, 1992.11, 1993.7 9 に高度 785, 550, $300 \mathrm{~m}$ の 3 地点 で気温観測を行った。

今回は残雪観察ならびに無雪季の気温観測を行っ た。気温観測点は凹地底日陰部分（535 m）の地表 0.2 $\mathrm{m}$, 風穴 $(540 \mathrm{~m})$ の中，凹地上部日当り斜面 $(545 \mathrm{~m})$ の地表 $1 \mathrm{~m}$ である(それぞれ図 1 の底，穴，上)。残雪

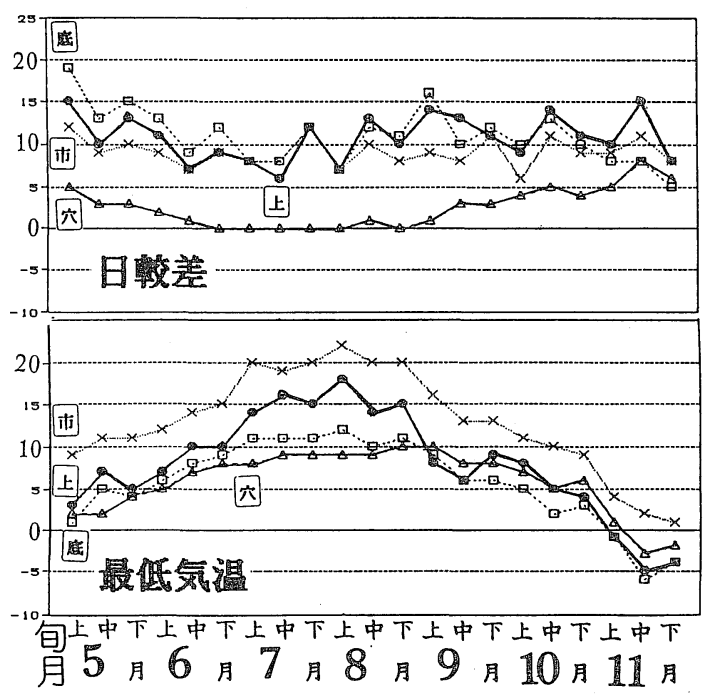

図 4 地点の旬平均気温 $(1995.5 \sim 11)$ : 最低気温と 日較差。市: 天童市消防署 $(115 \mathrm{~cm})$, 上： ジャガラモガラ凹地の上部日当り斜面，穴： 風穴, 底: 凹地底日蔭
興野寛久 (足利商高) ・阿子島功（山形大）

は凹地上部斜面と凹地底日陰部分とで約 10 日の差が ある。

風穴出口の月平均気温 (5～11 月) は，蔵王山頂付近 (約 $1,700 \mathrm{~m}$ ) のそれより低い。凹地底の月平均気温は 蔵王山頂より高いが，蔵王温泉(約 $1,000 \mathrm{~m}$ ) より低い。

風穴の気温は雪から現れる 5 月上旬の $2^{\circ} \mathrm{C}$ からはじ まり 8 月末 $12^{\circ} \mathrm{C}$ までじりじりと昇温する。 9 月より外 気とともに変化が大きくなり，(11月中旬, 凹地底の最 低気温 $-12^{\circ} \mathrm{C}$ のとき)最低 $-7^{\circ} \mathrm{C}$ に達するが, そのまま 保存されるわけではない。風穴の温度は外気温ととも に周年変化し，越年しない。

A. 風穴に与えられたはずの熱量（度・時）風穴の
温度＜気温（凹地上部観測点）となる 5 月上旬 11
月末 $(5.8 \sim 15,9.2 \sim 18$ 欠測）の間に与えられた熱
量 $\rightarrow>31,049$ (度・時)

岩石の比熱を考慮すべき

B. 風穴の昇温をもたらした熱量（度・時） 5 月中旬 $\sim 10$ 月末に $\left(6^{\circ} \rightarrow 12^{\circ}\right)$ なのでその間に受けた熱量 11,880 (度・時)

C. 放射冷却による冷却と積雪による冷却 春の冷え込み分 $\quad \rightarrow \quad 66$ (度・時) 秋の冷え込み分 $\rightarrow \quad$ 278（度・時） 積雪による降温（6.5 ケ月で 2 ～ $3^{\circ}$ の低下として） $\rightarrow 9,600 \sim 14,400$ (度・時)

放射冷却が生じたとみられる日数は 5 月 $35 \%, 10$ 月 $52 \%$ であり，5～11月平均は $31 \%$ である。

年間を通じて風穴（をつくる岩屑の）の熱収支を考 えると以下のようになる; 風穴に与えられたはずの熱 量（A. 単位：度・時）に対して，風穴の昇温をもたら した熱量 (B) は $1 / 3$ 程度であるが，岩屑の比熱を考慮 すれば，ほぼ相当するともいえる。

一方，風穴の岩屑の冷却をもたらすのは，無雪季の 
放射冷却による低温と積雪による低温であるが，それ ぞれを積算して比べる $(\mathrm{C})$ と冷気源としては積雪から の伝導が圧倒的に多いことになる。しかし，現在開口
している風穴は多くないので，冷気湖形成の主要因と して風穴の冷気のみとはかぎらず,凹地であること,日 陰条件など昇温しない要因も検討すべきであろう。

\section{ヒートアイランド強度の日変化・年変化}

都市の周囲が水田の場合

村 田 英 彦（東北大・院）

\section{1. 目的と方法}

ヒートアイランドの発達の程度は, 都市とその郊外 地域との気温差（「ヒートアイランド強度」と称する） で表される。ところが，都市の条件が同じであっても 対照する郊外地条件が異なれば，この気温差の持つ意 味も異なってくると考えられる。日本の場合には郊外 が水田であることが多いが，水田は季節によってその 表面被覆が裸地，水面，草地と変化する。榊原 (1994) は移動観測の観測值によってこの気温差の季節による 差異を確認し，一般に言われている冬季の静穏な晴夜 だけでなく，夏季の昼間にも明瞭なヒートアイランド が出現していることを示した。本研究では，主に気温 の定点観測を行うことによって，ヒートアイランド強 度の詳細な日変化・年変化の特徵を明らかにした。

観測は 1995 年 3 月〜 1996 年 1 月の期間，宮城県古 川市において行った。古川市の人口はおよそ 7 万人で あり，また周辺はほぼ平坦な水田地帯である。観測は 市街地と水田地帯の合計 4 ケ所で実施したが，ここで は市街地と水田を代表する 2 地点の比較を中心に論ず る。

2. 日変化

（1） 冬季晴天日の気温日変化

日の出後の気温上昇時には都市と水田の気温差はほ とんどみられない。最高気温出現時以降，両者の気温 差が拡大し，日没後数時間で最大となる。その後，こ の気温差は日の出前までほぼ同じ值で推移するか，僅 かに縮小するという推移を示す (図 (a))。

（2）夏季晴天日の気温日変化

日の出後，水田では急激に気温が上昇し，都市より も高温になる。しかし，その後水田では気温の上昇が 著しく鈍くなることにより，都市の気温が相対的に高 くなる。ここで榊原（1994）が指摘した「昼間のヒー トアイランド」が出現している。都市と水田の気温差 は日没前後に最大 $\left(3 \sim 4^{\circ} \mathrm{C}\right)$ となりこの最大值は冬季の 夜間と同程度もしくはそれ以上であった（図(b))。
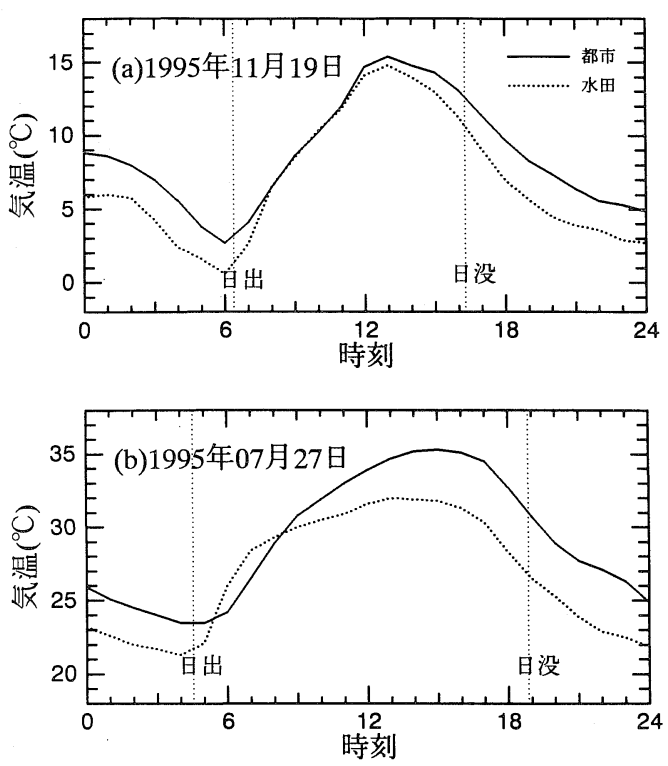

図 気温日変化の例（a）冬季晴天日 （b）夏季 晴天日

3. 年変化

昼間のヒートアイランド強度 (11 時〜 15 時の都市と 水田の気温差の平均）の年変化を調べたところ, 冬季 から夏季にかけて次第に増大し，また冬季にかけて減 少することがわかった。これを水田の表面被覆の変化 と比較したところ，水量よりも稲の成長 (草丈 $\times$ 茎数) の変化との対応関係が明瞭であった。これより, 夏季 の日中のヒートアイランドの主たる原因として稲の蒸 散活動が示唆された。

\section{参考文献}

榊原保志 (1994)：越谷市に見られるヒートアイラン ド強度一郊外が水田の場合一, 天気，41，515-523。 


\section{都市内丘陵周辺の気温分布}

田坂 郁 夫(福井工大)

都市の高温に対し，河川や公園は緩和効果をもつと いわれている。本調查は都市内にある丘陵が大規模な 公園として, 周辺市街地の気温分布に及ぼす影響をみ るために行ったものである。

観測を行った福井市の足羽山は市街地の南西部にあ る面積約 115 ha, 標高約 $100 \mathrm{~m}$ の丘陵で, 周辺は住宅 地となっている。今回はこの足羽山内および周辺に 34 の測点を設け, サーミスタ温度計を用いた移動観測を 実施した。観測日時は 1995 年 7 月 25 日 12 時〜26 日 12 時, 9 月 27 日 12 時〜28 日 12 時の 2 回で, それぞれ 3 時間ごとに気温を観測した。観測日の天気は 7 月が 快晴ないし晴れ, 9 月が晴れないし薄曇りであった。風 向・風速は 7 月の日中に海風である $4 \sim 5 \mathrm{~m} / \mathrm{s}$ の北風 が吹走していたほかは, 1 3 m/s の南なしい南西風で あった。

日中の気温分布をみると, 足羽山の中心部は市街地 よりも気温が低くなっている。このとき，等温線は丘 陵の輪郭に沿って走り, 足羽山が市街地の気温分布に 影響していることがわかる。また，足羽山の縁辺部に
は等温線が密集しており, 丘陵から市街地に至る範囲 で温度変化が大きくなっている。市街地と丘陵の温度 差は 7 月には約 $3{ }^{\circ} \mathrm{C}$ 達しているが， 9 月の観測では それよりも若干小さくなっている。一方夜間は, 足羽 山と市街地の温度差が小さく, 等温線の形状にも丘陵 の影響はみられない。観測域内における最低気温は足 羽山内に現れることが多いが，9月の観測には山麓部 で観測される例もみられた。

市街地から足羽山に及ぶ気温断面をみると，相対的 に高温である市街地の気温が低下を始めるのは，丘陵 に最も近い市街地の観測点である。気温はこの観測点 から丘陵にかけて急激に低下し，ある程度丘陵内部に 入ると一定になる。このような傾向は日中に顕著で あって, 夜間は市街地加丘陵にかけて, 連続的に気 温が低下し, 気温の急変帯はみられない。日中に気温 が低下し始める市街地の観測点は丘陵から約 $100 \mathrm{~m}$ ほど離れているに過ぎず，足羽山が市街地の気温を低 下させる効果は丘陵周辺の狭い範囲に限られていると いえる。
15:00 25, Jul.

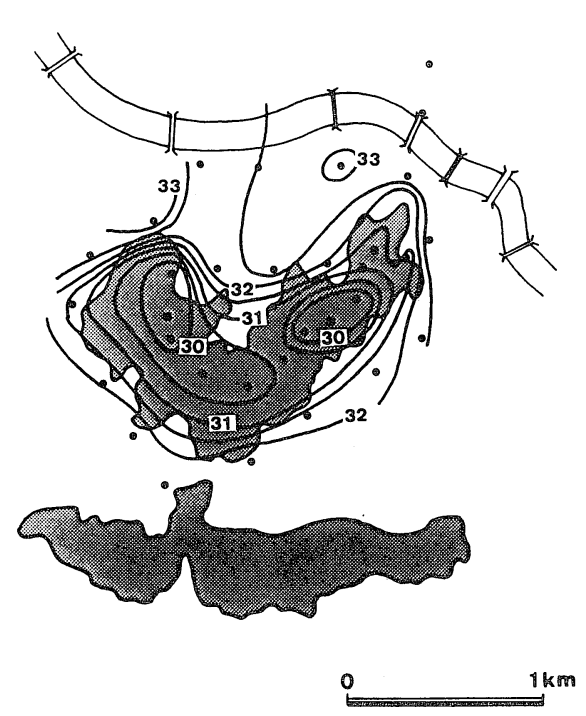

3:00 26, Jul.

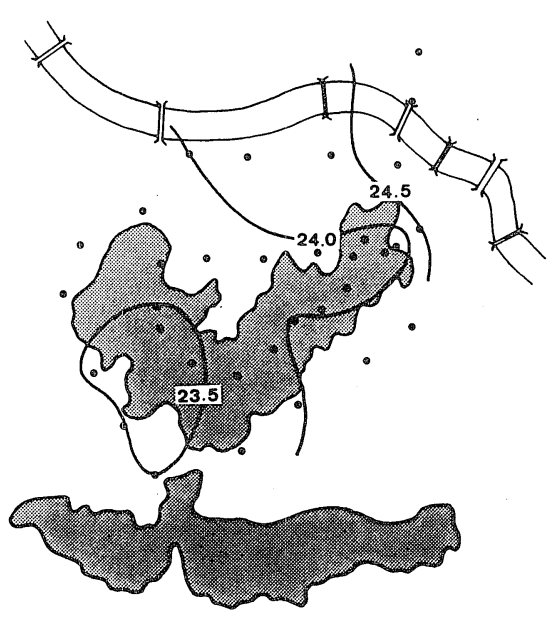

図足羽山周辺の気温分布 左図：日中（7月 25 日 15 時）右図：夜間（7月 26 日 3 時） 


\section{盛岡都市圏における大規模宅地開発の展開}

盛岡都市圈は東西を山地に狭まれ, 市域は北上川, 零 石川, 中津川によっていくつかに分断されているし, 北 部には農林水産省の試験場が立地しているため, 市街 地の拡大が難しい条件下にあった。

このような盛岡都市圏での戦後の宅地開発は盛岡駅 北西約 $5 \mathrm{~km}$ に位置する現在の青山地区での引上者用 住宅の建設から始まった。その後, 高度経済成長期初 期に至るまで小規模な宅地開発が，主として当時の市 街地の周辺部で活発にすすめられた。しかし, 開発対 象地の不足, 既存の社会資本 (公共諸施設) の負担能 力の限界, 宅地需要の急増などから大規模開発が求め られ，1965 年に県住宅供給公社(以下，公社と略す)が 観武台（23.8 ha）の造成に着手した。その後，公社は 1969 年に松園ニュータウン, 1977 年に湯沢団地, 1986 年にサンタウン松園の造成に着手している。以下，大 規模宅地開発 (開発面積 20 ha 以上) を中心にその展開 と特徵を示す。

民間開発業者による開発は国際興業グループ下にあ る岩手興業による 1974 年の滝沢ニュータウン造成に 始まる。同じ業者によって 1979 年に手代森ニュータウ ンの造成が行われ，その後他の業者が参入し，1982 年 に巣子ニュータウン, 1983 年に桜台ニュータウン, 1986 年に小鳥沢ニュータウン，そして 1991 年にあす み野の造成が開始された。土地区画整理事業による宅 地開発はスプロールへの対応として行われているもの が多く, 1985 年に門・東安庭地区, 1987 年に大釜地区, 1990 年に矢幅駅東地区, 1991 年に耳取地区, そして 1992 年に室小路地区の事業が開始されている。また, 1980 年に始められている仙北西地区の盛岡市による 事業は, 1970 年の盛岡市総合計画において計画された 盛岡駅東地区開発の一部で, 1994 年から地域振興整備 公団によって着手された盛岡南新都市開発整備事業と 密接な関係をもっている。

次にこの開発過程の中でみいだされる特徵をみてい こう。まず, 大規模宅地開発は高度経済成長期以降, 特 に 1980 年代に入ってから活発化している。これは仙台

\section{千 葉 昭 彦 (東北学院大)}

などの都市圏と比べると遅くなっている。

次に開発主体に関してみると, 20 ha 以上の開発で は民間開発主体はすべて県外の開発業者になってい る。大規模宅地開発といっても松園ニュータウン，盛 岡南新都市開発，仙北西区画整理を除けばすべて 50 ha未満であって開発規模はそれほど大きいものでは ない。この 50 ha をこえる開発は公的主体に限られて いる。また, 主体と規模との関係を 5 ha 以上の開発で みると，全開発面積の $63.1 \%$ が公的主体による開発 で，特に 50 haをこす上記 3 開発地だけで全体の $45.8 \%$ を占めている。民間開発業者は全開発面積の $24.9 \%$ を占めているが，地元民間開発業者によるもの はすべて 20 ha 以下の規模であり, 県外開発業者によ る開発は花やはばを除けばすべて 20 ha をこす開発で ある。とはい光，その規模は最大が滝沢ニュータウン の 49.2 ha であるので，全国的にみた場合には必ずし も大きいものとはいえない。

20 ha 以上の開発地での有効宅地率は，時系列的に 低下傾向もみられる。しかし，それ以上に主体別での 相違が明確で, 公的主体の方が民間主体よりもその值 は小さくなる傾向がみられる。

開発地の個性化は 1986 年のサンタウン松園以降に 本格化しているとみられる。これは仙台などの都市圈 では高度経済成長終了直後から活発化してきているの と比べると，遅くなっている。

宅地開発が成立するためには生活のための諸施設の 整備が不可欠となる。しかしそれらは必ずしもすべて 自らの開発地内に立地する必要があるとは限らない。 そこで諸施設利用状況を小学校の学区でみると, 20 ha 以下の開発地はすべてが，そして 20 ha 以上の開発地 でもその多くが既成市街地や他の開発地に立地する小 学校に依存している。つまり, 盛岡都市圈では市街地 が拡大した形状での開発が多く，自らの開発地内に小 学校を整備している “飛び地”的な開発は 5 つの開発 地に限られている。これらはすべて公的主体によるも のである。 


\title{
都市化に伴う土地利用変化と地形条件
}

仙台都市圏における GIS を用いた分析

\begin{abstract}
青柳光太郎（東北学院大）・鈴木 希（株 セント）・新田将人（仙台市立三条中）・
\end{abstract} 本間章彦（村上市立大栗田中）

都市近郊に扔ける土地利用変化として, 都市的土地 利用の拡大が顕著にみられる。1960 年頃以前は, 農用 地からの転換が主であったが，それ以後は丘陵地の利 用に，急速に依存する割合が高まった。仙台都市圏は その傾向が著しくあらわれた地域の 1 つである。本研 究は, まず, はじめに植生類型の分布をとらえ, 次に それらの変化と地形条件, 市街地から距離との関連を 捉えることを目的とする。なお，対象地域は，5 万分の 1 地形図仙台，吉岡図幅の広瀬川・七北田川流域であ る。

作業の手順は次の通りである。

まず，本研究では，吉岡・広木（1974）の仙台市と その周辺の現存植生図（昭和 $26 \cdot 48$ 年現在）と環境庁 (1988)の宮城県植生図，また地形分類図を資料として 用いた。東北学院大学文学部史学科地理学教室に導入
されている, 地理情報解析システム (GIS) の 1 つであ る $\mathrm{ARC} / \mathrm{INFO}$ を利用し，まずはじめに, 現存植生図を デジタイジングし，3枚の図を作成した。そして，3 枚 の植生図を重稀わせることによって, 約 30 年間の土 地利用（植生）の変化を捉えた。次に地形分類図をも デジタイジングを行い，これと植生図を重ね合わせる ことによって地形条件との関連を捉えた。

以下，簡単にこれらの作業を通じて明らかになった ことを列挙する。

(1) 植生図では，21 項目に分けて把握されている が，対象地域にみられる植生は，クリコナラ林，水田， 畑，アカマツ林，市街地，スギ植林の 6 項目が多く，各 年次ともにこれらの合計で，95\%を超える。

(2) 3 時点の経時的な変化をみると, 市街地の著し い拡大がみられる。面積の構成比の変化は，1951 年

表 植生類型別面積の推移

\begin{tabular}{|c|c|c|c|c|c|c|}
\hline & 1951 年 & & 1973 年 & & 1984 年 & \\
\hline & 面積 ha & 構成比 & 面積 ha & 構成比 & 面積 ha & 構成比 \\
\hline モミ・イヌブナ林 & 72.0 & 0.2 & 67.9 & 0.2 & 68.7 & 0.2 \\
\hline クリコナラ林 & $17,576.1$ & 47.7 & $14,940.7$ & 40.5 & $11,101.9$ & 30.1 \\
\hline スギ植林 & $1,811.0$ & 4.9 & $2,441.5$ & 6.6 & $3,559.4$ & 9.7 \\
\hline ヒノキ植林 & 612.9 & 1.7 & 56.2 & 0.2 & & 0.0 \\
\hline アカマツ林 & $2,825.1$ & 7.7 & $2,251.0$ & 6.1 & $2,475.5$ & 6.7 \\
\hline クロマツ林 & 0.0 & 0.0 & 3.7 & 0.0 & 53.0 & 0.1 \\
\hline 水田 & $7,146.7$ & 19.4 & $6,448.4$ & 17.5 & $5,617.6$ & 15.2 \\
\hline 畑 & $2,999.0$ & 8.1 & $1,312.3$ & 3.6 & 850.7 & 2.3 \\
\hline 竹林 & 2.3 & 0.0 & 0.0 & 0.0 & 0.0 & 0.0 \\
\hline 果樹園 & 14.1 & 0.0 & 85.9 & 0.2 & 105.1 & 0.3 \\
\hline 河畔林 & 25.5 & 0.1 & 84.2 & 0.2 & 177.4 & 0.5 \\
\hline ススキ & 395.7 & 1.1 & 214.9 & 0.6 & 77.2 & 0.2 \\
\hline 裸地 & 125.5 & 0.3 & 295.3 & 0.8 & 0.0 & 0.0 \\
\hline 開放水域 & 430.3 & 1.2 & 370.8 & 1.0 & 422.2 & 1.1 \\
\hline 市街地 & $2,744.2$ & 7.4 & $8,119.1$ & 22.0 & $11,923.7$ & 32.4 \\
\hline 公園緑地 & 72.6 & 0.2 & 161.1 & 0.4 & 355.6 & 1.0 \\
\hline 桑原 & & 0.0 & & 0.0 & 1.1 & 0.0 \\
\hline イヌシデ・アカシデ & & 0.0 & & 0.0 & 63.9 & 0.2 \\
\hline 合 & $36,853.0$ & 100.0 & $36,853.0$ & 100.0 & $36,853.0$ & 100.0 \\
\hline
\end{tabular}


$7.4 \%, 73$ 年 $22.0 \%, 84$ 年 $32.4 \%$ である。

(3) 前に述べたことと関連するが, 農地と林地の減 少が顕著である。農地では特に畑地の減少の割合が大 きい。

(4) 林地では, 特に丘陵斜面のクリ・コナラ二次林 からの市街地化が顕著である。丘陵地のクリ・コナラ 林が宅地開発のターゲットになっているように感じら れる。

(5) しかし,一方ではスギ植林の増加がみられる。特 に丘陵斜面のクリ・コナラ林からの変化が多いが，谷 底面での水田からのスギ林化も一部で進行した。

(6) スギ植林化が進行したが，その内容は単純では なく，他の植生類型との差引増によってもたらされた ものであり複雑である。

(7) また，旧市街地を核として，外延的拡大がみら
れ，他の核が形成されたわけではない。

これらの結果は，1984 年までの変化であった。その 後, 泉中央駅を中心に副都心が形成されたと考えられ， また，総体的には仙台都市圏の外延的拡大が，特に北 部を主として進行中であり，これらが植生にどのよう な変化をもたらしたかをとらえる必要があると考えら れる。

今後の課題としては, 上記のことに加えて, 農業・ 林業に携わっていた人々が都市化という現象にどのよ うに対応してきたのかを，明らかにする必要があると 考える。また，丘陵地の住宅地開発について，行政あ るいは開発業者がどのような計画を持ち，実際にどの ような開発がなされてきたのかを，オーバレイし考え ていくことも重要であろう。

\section{活断層沿いの土地利用規制をめぐる問題点}

地域の防災性を高めるために，土地利用規制を含む 根本的かつ事前的対応の必要性が指摘されている。こ のような規制（以下，防災型土地利用規制と呼ぶ）は 大きな効果が期待される一方で，住民の合意なしには 単なるアイデアにすぎない。一般的な計画プロセスに 沿って見るならば，「1，必要性の発意 $\rightarrow 2$.アジェン ダ (議題) 化 $\rightarrow 3$. 費用対効果等の検討 $\rightarrow 4$. 代替案の 選択 $\rightarrow 5$. 制度・体制の確立」という流れの中で，その 出発点にあたる 1 2 2 レ゙ルの検討が必要である。そこ で本報告では，まず，防災型土地利用規制の必要性に 対する活断層研究者の意見・提案を整理し，その対立 軸や取り組むべき課題を明らかにした。次に，市街地 直下に活断層が走る仙台市を事例に，防災型土地利用 規制の社会的受容可能性に関する住民意識の把握を試 みた。

1）活断層研究者による土地利用規制への意向 1990 年以降の文献をもとに整理を試みた。中田高氏 は，カリフォルニア州の建築活動の禁止を含む厳しい 土地利用規制法を紹介し，日本でも早急に実施すべき と提案しているのに対し，山崎晴雄氏らはこれに反対 している。中田氏は「活断層の変位に伴う直接的地盤 破壊による被害は不可避で，活断層上で特に被害が著 しい」とするのに対して，山崎氏は「格段に著しいと はいえない」としている。また渡辺満久氏や池田安隆 氏は，活断層の活動がきわめて長い時間間隔をおいて

\section{増田 聡・村山良之（東北大）}

発生することやその不規則性から，住宅の規制には否 定的な立場と推測される。活断層の活動特性，活動時 期の予測，さらには被害想定等の各段階におけるきわ めて大きな不確実性の存在が，専門家の間での意見の 相違の背景にある。つまり多様な不確実性を前提とし た政策判断を迫られていることになる。しかし建造物 の用途毎にみると，強弱の差はあれ何らかの規則（住 宅の排除，病院等の排除，建築基準の上乗せ等）を行 うべきという点では専門家の意向はむしろ一致してお り，その差は相対的なものといえる。社会的受容に向 けて，不確実性を含めた積極的な情報公開が必要であ るが，この点でも専門家の意見は一致している。

2）防災型土地利用規制の社会的受容可能性

このような新たな計画制度の導入には, 個人の土地 利用・建築活動の自由に対する公的介入（規制）が社 会的に受け入れられるかを評価する必要がある。そこ で，本格調査を設計・実施するためのプレ調査として， 具体的な規制案のイメージを提示しながら住民意識の アンケートを実施した。ある程度の標本数を短期間に 集めるため，阪神大震災後に仙台で開催された 3 シン ポジウムの機会を捉えて, 参加者に対する調查を実施 した（東北地理学会 131 票，日専連・宮城生協 54 票， 土木学会東北支部 95 票, 有効回答数 280 , 受付で調查 票を配布し終了後に回収)。一般市民の意識分布とは乘 離が大きいものの，自主的に参加した「比較的意識の 
高い層」の調査であると考えて評価を試みた。

まず「正確な情報提供の不在」を指摘できる。自主 的参加者のような関心を有する層においても,「活断層 の存在自体を知らない, 最近初めて知った」者が多く, 特に専門学会と関係のない一般市民でこの傾向が強 い。また情報源として，マスコミやロコミが多く，専 門家の提案と同様に正確な公的情報の提供が強く求め られる。次に,「地震危険地区で何らかの土地利用規制 を行うこと」には, 9 割近い賛成があるのに対して,「防 災目的からの個人の権利制限の是非」を尋ねると, 賛
否と判断不能が拮抗してくる。この矛盾自体が住民意 識の反映であり, 受容可能な規制内容の精查が重要で ある。第 3 に，急傾斜地・崩壊危険地域等の規制導入 済みの地域以上に，活断層上の各種規制案への賛成率 は高いが，同時に移転補償等の条件整備が求められて いる。最後に，災害知識の有無や住民属性が受容可能 性を大きく左右しており，活断層との位置関係等の地 域特性を含めた大標本による本格調査を行い, 意識形 成メカニズムの解明が必要である。

\section{山形県における金融の地域構造}

\section{1. 目的}

本研究は，山形県における資金の蓄積と投資が空間 的にどのようになされ，資金がどのように流動・循環 しているかについて考察したものである。

2. 山形県内の金融機関の歴史と現状

山形県では戦時金融統制の一環として強力に推進さ れた「一県一行主義」が貫徹されず，内陸部と庄内地 方の 2 地域の銀行を統合することができず，山形銀行 と荘内銀行の設立に留まった。また平成元年に相互銀 行から普通銀行に転換した第二地方銀行は 2 行存在す る(山形しあわせ銀行, 殖産銀行)。この他に信用金庫 (山形，米沢，酒田，鶴岡，新庄の各信用金庫)，信用 組合, 農協等が主な金融機関である。しかしながら, 都 市銀行や信託銀行，県外に本店を置く地方銀行の立地 は少ない。

\section{3. 山形県内の金融動向}

1974 年以降 20 年間の山形県の金融動向をみると, 全国銀行（都市銀行，信託銀行，地方銀行，第二地方 銀行など）の預金量は絶対減はないものの，その増加 率は鈍化している。一方，農協の貯金量は絶対減はな いものの, 貯金の伸び率は徐々に低下する傾向にある。

全国銀行の貸出量は預金量の推移と比較的類似した 動向を示す。主な貸出先は製造業, 卸売・小売業, 個 人の三部門である。とりわけ, 1980 年代半ば以降, 製 造業が最大の融資先となっている。製造業への融資残 高の業種構成は 1980 年代前半までは繊維，木材・木製 品, 食料品が中心であったが, 電気機器への投資が積 極的に進み，次第にその地位を高めた。また，個人向 け貸し出しの伸びについては様々なローン商品が金融 機関のリテール分野に扔ける収益商品として開発され

\section{牧之瀬 泰 志（東北大・院）}

たことが大きい。一方，農協の貸出量は絶対減が続く など激しく変動している。

なお有価証券については, 昭和 50 年以降, 山形県で も国債や地方債の発行が積極的に行われてきており， なかでも社債や株式などの有価証券の増加が顕著であ る。銀行にとっては有価証券業務は貸出業務に次いで 重要な資金運用方法になっている。

4. 資金の地域間流動

コール市場において都市銀行がマネー・ポジション に，地方銀行，信用金庫などの金融機関がローン・ポ ジションに位置する我が国の資金循環構造の中で，山 形県は恒常的に資金の供給地域として機能し，県外他 地域に資金を流出させてきた。他県と比較して有利な 貸出先が十分とは言えない山形県の貸し出し状況は低 位の預貸率に表れており,とりわけ 1980 年代半ば以降 の農協の預貸率の低下は顕著である。これは貸し出し の伸び悩みに加え，農協の余裕金が上部機関を通じて 有価証券などに運用される割合が増加したことに起因 している。

資金の循環・流動は国民経済レベルのみならず，県 内の地域間においてもみられる。その点を各市町村の 資金ポジションから検討すると比較的安定している。 この資金流動の構造は金融機関の性格により異なって おり，地方銀行，第二地方銀行などにおいては，小規 模都市や郡部から県内の中核都市 (人口 10 万人以上を 有する山形市, 米沢市等)へと資金は流動している。一 方，農協金融においては県内のほとんどの都市から郡 部に向けて資金流動しており，全国銀行とは逆の資金 流動が行われている。一般銀行と農協金融においては 資金の需要・供給の位置づけが異なっており，このた 


\section{宮城県北部地域における交通現象変化}

—その要因と影響

\section{平出 雅 彦 (東北大。院)}

本研究は, 現在の日本の交通現象の形成に大きな影 響を与えたモータリゼーションの, 宮城県北部の農村 地域における実態を分析し，その要因，及び影響につ いて明らかにすることを目的とする。

対象とした地域は, 宮城県北部の登米郡内の 6 町で ある。登米郡は仙台平野の北端部に位置する農村地域 であり, 農地率, 及び農家世帯率はそれぞれ約 $40 \%$ と 約 $55 \%$ である。

当地域のモータリゼーションは貨物車の普及から始 まった。当地域の道路は, 1965 年以前はほとんどがま だ未舗装の状態であったが, 自動車貨物輸送の活発化 により道路破壊が進行したため, 徐々に舗装・改良が 進み, 1975 年頃までには各町を結ぶ主要な道路の舗装 が完了した。道路整備はその後の自家用車が普及する 基盤となった。

宮城県においては，自動車普及は，1970 年頃までは 都市部が先行したが, 1970 年代後半からは, 郡部での 普及率の伸びが大きくなる。普通・小型乗用車の普及 状態はどの地域もほぼ一様であるが, 軽自動車の普及 状態は地域による差が大きく, 登米郡での普及率は県 平均よりかなり高い。さらに登米郡の中でも中田町で は，相対的に早い時期から普及率が高い。これは工場 の進出の影響である。つまり工場進出が通勤手段とし ての自家用車の普及の契機となった。

中田町では県外資本の工場の立地が 1960 年代後半 から活発化し, 周辺の町に比べて, 多くの工場が進出 した。進出工場の主な業種は, 女子労働力依存型とも いうべき, 電子部品, 縫製業などであり, そのため女 子製造業従事者数が大幅に増加した。交代勤務制の採 用などもあって，路線バスの利用が難しく，工場によ る送迎バスなどもさほど活発でなかったため, 当初は 大多数の女子従業員は徒歩や自転車で通勤をしてい た。しかし就職後 $2 \sim 3$ 年してから, 多くの人が免許を
取得し，車で通勤するようになった。

なお中田町での軽自動車の普及には, このほかに農 作業用の軽トラックの普及も影響している。農作業の 機械化や道路整備の進捗と共に, 軽トラックの必要性 も増してきたが，農繁期の利用が主であり，毎日使う わけではない。このため, 経済的制約の中で 2 台目を 買うに当たり，軽トラックを選び，町内の工場など勤 務先が近い場合が多かった女性が，これを通勤手段と して用い，買い物などにも使用するようになった。

当地域においても, 自動車の普及と平行して, 商業 施設の立地にも変化が起こり, 1981 年には登米郡の中 心地佐沼に仙台に本部を置く地元スーパーチェーンの 大型店が開設された。この大型店は既存の商店街に立 地したが，近年進出した大型店は市街地から離れてお り，私的交通手段以外の利用が難しいものとなってい る。当地域では, 自動車が普及する以前は行商などの 利用が多く，また農家が多く野菜などは自給していた ため，日常的に食料を買いに行くことは少なかった。し かし現在では最寄品であっても, 女性が自動車を使っ て買い物に出かけるようになっている。

自動車の普及は公共交通にも大きな影響を及ぼし た。この地域のバスの利用客数は現在ではピーク時の $1 / 3$ 程度まで落ち込んでいる。宮城県全体の現在のバ ス利用が，ピーク時の $2 / 3$ 程度であることと比較して も, 自家用車の利用に都市部ほど制限のないこの地域 における減少の度合いの大きさがわかる。とくに女性 への自動車の普及によって, 路線バスの利用は急激に 落ち込むこととなり，路線の代替化も進行した。

宮城県北部の地域におけるモータリゼーションの進 展には工場の進出が大きな契機となっていた。特に， 女性の自動車利用が，大型店の立地の変化，バス交通 の衰退に深く関わっている。 


\section{新潟県湯沢町におけるリゾートマンション景観形成に関する一考察}

\section{川口裕 輔（東北大・院）}

\section{（1）はじめに}

新潟県湯沢町は上越新幹線，関越自動車道の完成に より，首都圏との近接性が強まり，スキーリゾートを 目的としたマンション建設が昭和 60 年以降急激に進 んだ。本研究は土地改良事業が施行された農地で急激 なリゾートマンション開発の進んだ，湯沢町中子地区 を対象に，リゾートマンション景観形成要因を考察し た。リゾートマンション景観の存在する同町南東部に 位置する中子地区には, 20 ha の土地に 11 棟のリゾー トマンションが建設された。

(2) 地域の概要と歴史的背景

対象地域の中子地区は，地形的に魚野川と大源太川 の汇濫原に位置している。中子地区は明治時代末期ま で農地としての開発が進まず，江戸時代から耕地整備 の進んだ，段丘面上に位置する周辺集落と比較して新 開地であった。中子地区は，上越線清水トンネル工事 に伴う工事関係者の定住化と戦前戦後の周辺集落から の分家により，形成されたといわれているが詳しいこ とは不明である。

中子地区の農地は, 昭和 40 年代後半に土地改良事業 が施行された。しかし，区画整理に伴う観光開発に期 待した土地所有者の総意で, 北部 20 ha の農地は, 農業 振興地域の農用地区域指定を受けなかった。中子地区 のリゾートマンション 11 棟は, すべて北部 20 ha に立 地している。

（3）土地台帳に基づく分析

中子地区北部 20 ha の農地について土地台帳に基づ
き,土地改良事業後の新地番が施行された昭和 51 年以 降の農地転用の実態を分析した結果，以下のことが明 らかになった。1）昭和 51 年の土地改良時点での土地 所有者の居住地分布のうち，中子地区に占める割合は 39.7\%であった。2）リゾートマンションに関連した 農地転用が進む前と思われる昭和 57 年以前に農地転 用を行った土地所有者の居住地分布のうち，中子地区 に占める割合は $13.3 \%$ であった。 3）リゾートマン ションに関連した農地転用が進んだと思われる昭和 57 年以降に農地転用を行った土地所有者の居住地分 布のうち，中子地区に占める割合は $40.7 \%$ であった。

以上の結果から，中子地区は周辺集落居住者により 農地転用が進められたことが明らかになった。

(4) まとめ

リゾートマンション開発業者数社からの聴き取り調 查の結果，中子地区にマンションを開発しようと決め た複数の理由の中に, 農用地区域指定の有無と農地の 取得の容易さが含まれていた。このことから，対象地 域の中子地区にリゾートマンション景観が形成された 要因として，農用地区域未指定であったこと，周辺集 落居住者による農地転用の促進に伴う，転用の生じや すい社会環境の発生があげられる。全国的なりゾート マンションブームといった背景において，リゾートマ ンション開発業者の思惑が，その社会環境に適合した ことにより，リゾートマンション景観が形成されたの である。

\section{仙台市における宿泊機能の立地動向}

松 村 公 明（秋田大）

本研究の目的は，仙台市における宿泊機能の立地動 向にみられる地域的特徵を，東北地方主要都市の動向 を踏まえながら考察することである。ここで述べる宿 泊機能とは，旅館業法によって定義される旅館業，す なわち，ホテル・旅館等の宿泊施設の都市機能として の側面を指す。また，宿泊機能の新規立地に着目し， 1970 年代以降, 都市中心市街地の宿泊機能の主体と なった民間資本によるホテルを中心に述べることとす る。
1996 年 5 月現在, 発表者の算出によれば，東北地方 の人口 20 万以上の 8 都市市街地(市街地が分散するい わきを除く)におけるホテル客室総数は，20,862 室で あり，そのうち，仙台に $34 \%$ ，盛岡と秋田に $13 \%$ ，郡 山に $11 \%$ が立地し，以下，青森，山形，八戸，福島の 順である。客室数からみた東北地方主要都市の宿泊機 能は，1）地方内・県内に扔ける首位都市としての卓 越性，2）高速交通網の結節中心地としての拠点性， 3）地域住民需要が発生する都市・都市圈の人口規模, 
4）旅行者需要が発生する大都市圏との時間距離, 等の 要因によって影響を受けてきたと考えられる。

仙台は, 東北地方の都市において, 最も早期にホテ ルの増加期を経験し, その後 4 回の増加期を有する。ま ず，増加期の第 I 期は，1973 年から 1975 年であり，こ の時期は，わが国に扔ける第 2 次ホテル建設ブームに 対応する。たとえば，1996 年における仙台のホテル客 室総数のおよそ $23 \%$ は，第 I期に立地したホテルに よって占められる。つぎに，第 II 期は，1980 年から 1982 年であり,この時期は，おもに東北新幹線の開業 （1982 年）が，仙台を含む新幹線沿線の都市において， 宿泊機能を増大させる要因となっている。仙台では, 1996 年のホテル客室総数のおよそ $17 \%$, 盛岡では実に $46 \%$ が,第 II 期に開業したホテルによって占められて いる。しかしながら, 盛岡では, この急速で大量の客 室集積の結果, 客室の供給過剩となり，1983 年から 1992 年まで, 新規のホテルの立地は事実上, 皆無と なった。いずれにせよ，東北地方の主要都市において は，ホテルの集積が進行する過程で，とりわけ冬季間 の客室稼働率の低下がみられ，客室主体，すなわち基 本的機能に依存する宿泊特化型のホテルの立地には限 界が生じた。そのため, 仙台においては, 会議室, 宴 会場など付随的機能を備えた付随施設設置型, 婚礼な ぞ付随的機能に重点を置く準複合機能型,さらには, 大 規模なコンベンション開催が可能な複合機能型など, 多様な機能を保持するホテルが，それぞれ競合しなが ら機能分担するかたちとなっている。その結果, 第 III 期から第 V 期にかけては, 年平均の増加率は, 第 I 期。
第 II 期を下回るものの, 増加率は相対的に長期に継続 し,客室供給の停滞期をほとんど挟まなくなってきた。 仙台中心部におけるホテルの立地は，仙台駅を結節 点とする仙台駅西側の CBD に顕著である。青葉通り をセクターの主軸とすると，とりわけ，北側は定禅寺 通りまで, 南側は北目町通りと五ツ橋通りまでの範囲 である。しかしながら，その核心部に位置する区域， なわち, 愛宕上杉（東五番丁）通りと広瀬通り, 国分 町通り, 南町通りによって囲まれた地域は, 近年まで, ホテルの新規立地の空白域となってきた。このことは， CBD の中央部が，すでに金融を主体とする業務機能・ 小売機能によって充填され, 機能的に純化しており, 宿 泊機能がそれら都心機能を補完するかたちで, 外周部 に立地してきたことを示すと同時に，他の主要都市と 比べて, 宿泊機能にとって良好な立地条件を示す地点 が広範囲であることを表す。

近年には, 既存の CBD から遠隔な, 青葉区北部から 泉区に 3 つのホルが進出した。これらは, 大規模な コンベンション機能を有する複合機能型であるととも に, 新規の地域住民需要を喚起しょうとしている。

これらホテルの動向に対して, 仙台の CBD に位置 する旅館は，旅館組合加入のものだけでも，1973 年か ら 1992 年の 20 年間に, 移転・脱退を含め 108 店から 30 店へと減少した。仙台の CBD の核心は, 仙台駅方向 に相対的に移動したとはいえ, CBD 自体は面的拡大を 遂げた。すなわち旅館は, 位置的な立地条件が依然と して良好であるにもかかわらず，地価の上昇および都 心空間の立体化に適応困難となったと考えられる。

\section{東京都大田区における中小工場の存在形態}

一一矢口・下丸子地区を事例に一

\section{伊 藝 直 哉（東北大・研）}

\section{I. はじめに}

本研究は近年の経済動向の中で, 大きな影響を受け てきたであろう大都市の中小工場に着目し, 大都市の 工業分散政策や近年の経済動向の中で，経営を存続さ せてきた要因を明らかにするための 1 つの試みであ る。対象地域の中小工場の事業形態や取引形態を分析 し, 住工混在地域という地域性を考慮しながら, 大都 市における中小工場の存在形態を明らかにしていく。

対象地域は大田区矢口・下丸子地区とする。工場数 は 1993 年に 577 軒であり, 大田区の総工場数の $8 \%$ を 占めている。1990 年からの 3 年間で $10.8 \%$ の減少率を
示しており大田区の中でも工場の減少が激しい地域の 一つではあるが，依然として工場の集積が最も高い地 域でもある。

\section{II. 中小工場の事業形態}

対象地域の産業は工業統計調査によると, 一般機械 や電気機械, 輸送機械といった機械工業に代表される。 しかし個々の工場の業務内容は切削加工や研磨加工と いった単一の加工作業を専門とする, 機械工業全般の 下請けを行う場合が多い。このことから事業の専門化 によって加工技術の向上がもたらされたと考えられ る。さらに対象地域は工場集積の高い大田区に在るこ 
とで, 切削, 研磨以外の事業内容の加工工場も隣接し ており，地域内，あるいは周辺で外注が行える。これ は短期間の外注を可能とし, 複数の加工工程を要する 受注にも短期に，かつ高い技術力で応える事を可能と させた。さらに技術力の高度化を図るために高額な高 精度工作機械を地域内の工場が分担するような形態で 導入している。これにより資本力の弱さを中小工場の 密集という利点で補いながら，より高精度な受注に応 えている。

\section{III. 中小工場取引先の地域的展開}

対象地域の中小工場の取引先は 1960 年代から 1970 年代にかけてはほとんど対象地域や大田区内で完結し ている。これが 1980 年代では神奈川県を中心に関東西 方へ拡がり, 1990 年代になると関東一円に拡がったの と同時に，関西や東北方面にまで地域的に大きく拡大 させている。取引先を地域的に拡大させることで受注 を確保するのと同時に，取引先に「商社」と呼ばれる 大工場と中小工場の仲介をなす業者との取引を増大さ せているのも 1990 年代の特徴である。仲介として「商 社」が介入することはコスト的にはマイナスではある が，労働力の小さな中工場としては営業部門を外部 化し，技術力のアピールとともに安定した受注を確保 できるというメリットが生まれている。

IV. 住工混在地域としての中小工場の集積

対象地域はかつてから工場の多い地域であったが, 1960 年代から 1980 年代前半にかけて大工場の移転の
反面，中小工場の増加が見られ，土地の細分化が進ん だことで住工の混在の程度が高まっている。1980 年代 後半からは工場は減少を続け，マンションといった共 同住宅，あるいは駐車場など土地利用が多様に展開さ れながらも, 依然として住工が混在した地域といえる。 また中小工場の経営者あるいは従業者の居住地は工場 と同一建物，あるいは対象地域周辺で多く，職住を対 象地域内で完結している者の割合が高い。また対象地 域には産業団体があり，工場のつながりをうむ機能を 果たしている。対象地域は土地利用と機能の両方の観 点からも住工混在地域といえる。

V. 扔わりに

対象地域の中小工場が存続してきた要因には, 中小 工場の経営形態が大きく関係している。まず加工作業 が中心の中小工場泌元，単一の作業工程に専門化した ことが技術力を向上させてきた。さらに多様な加工工 場が地域に密集することで, 短期間に高精度で複数工 程を要する受注を可能とし,経営を安定させてきた。ま た取引先を地域的に拡大させることで受注を確保しな がら,「商社」を取り込み営業部門を外部化することで も受注を安定させてきた。これらの特質が住工混在地 域という産業, 居住の両面での機能が高く, 両者が密 接に関わっている地域に培われ保たれながら, 相互に 作用していることが, 中小工場の存続をもたらしてい たのではないかといえよう。

\section{福島県浜通り中南部の東海道（古代道）の想定}

福島県は浜通り地方, 中通り地方, 会津地方に区分 されている。浜通りの地名の起源となった古代道の ルートを地図化したので, 報告した。この海道は常陸 の鹿島から, 宮城県の多賀城の構築と蝦夷地を律令制 の体制に組み入れる戦いを遂行するための交通路であ り, 海路を伴って, 戦略物資の輸送と浜通り北部の製 鉄遺跡から鉄製品の輸送の役割をもって，8 世紀の始 めから 9 世紀の 10 年代に利用された道路である。

海道は海岸沿いの常陸の磯原を通り, 大津港から, 西 に転じ，関本上から北に向かい，趾にある三面地蔵の 下を通り, 大梘から窪田の菊多郡衙に至る。富津で鮫 川を渡り, 大津から観音堂の後ろの崖を登り, 源道平, 後田を経て石塚にでて, JR 常磐線沿いに泉駅近くの鹿 島神社で北に向かい, 玉露からほぼ直線の道路となり,

\section{鈴 木 貞 夫 (内郷高)}

長孫, 関船, 湯本, 経から古代の駅と思われる御廐に 達する。

ここからほぼ $10 \mathrm{~km}$ 東進むと, 石城郡衙があり, 郡 司が津長に客の接待を頼んだ海路の存在を示す郡符木 簡の出土があった夏井の根岸に至る。ここから沖積平 野を北上し, 馬目, 名木, 長友, 白岩の鹿島社に至る。 この神社から北東の方向で丘陵を越え, 久之浜の鹿島 社付近で海岸にでる。久之浜からは金ケ沢の南の海触 崖の麓を通り, 現国道 6 号線と旧国道の間の尾根を越 して末続にでる。ここから, 夕筋までは, 絶壁の海蝕 崖に並行して, JR 常磐線の東側を通る。広野町本町の 鹿島社を通り, 北迫川を河口付近で渡り, 海道は東電 広野火発の敷地の西の直線の境界を楢葉町上台まで連 続する。山田浜の水田は条里制跡であり, 浜城の集落 


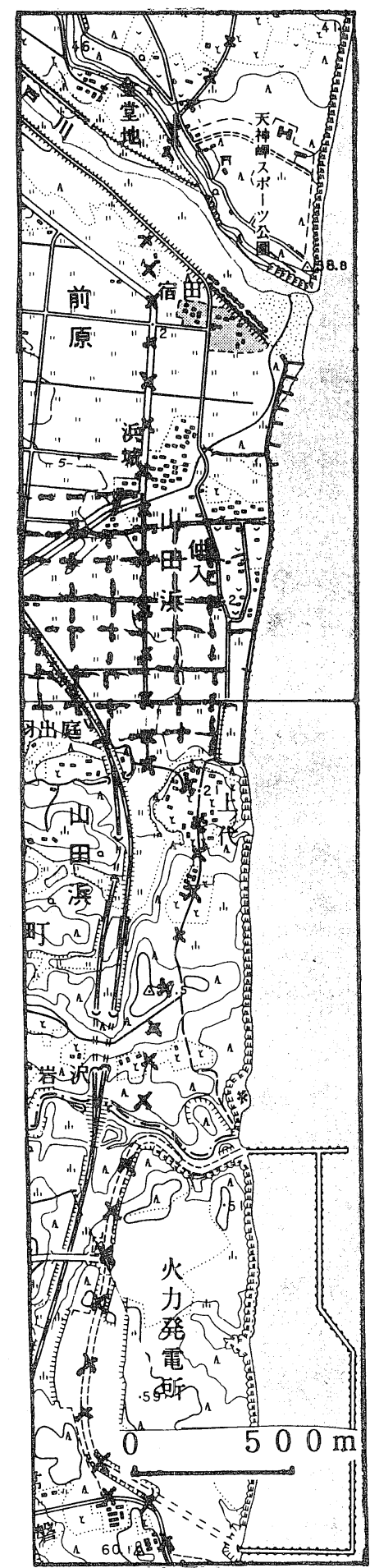

図 楢葉の海道と条里
を北上して，木戸川を渡り，金堂地の天満宮の鳥居の 南側の段丘崖を稲妻型に急坂を登る。下繁岡の段丘面 は絶壁の海岸線の近くを並行して通るが，波倉の近く で,一部海岸侵触ため崩落している。波倉の東電第 2 原 発の海水の取水口付近に渡河地点があり，発電所を東 南から西北の正門に向かい，そこから富岡の仏浜の条 里水田まで北進する。ここの道路は耕地整理をしてこ なかったので，条里の余剰帯としての古代道が検出さ れるのだが，この海道は道幅が $3 \mathrm{~m}$ 弱であり，誤差の 大きい地籍図では古代道は他の地区では検出されにく い。富岡川を河口の $500 \mathrm{~m}$ 上流で渡河して，段丘に小 浜廃寺跡があり，その西から東に向かう道路が古代か らの坂道である。小浜から小良ケ浜の深谷にくの字の ように，内陸部に湾曲するが，これは谷頭侵食谷が 1 $\mathrm{km}$ まできているので, 横断ができない。松葉原で海岸 にでて，熊川の八坂に直進する。この熊川は常陸国の 多賀郡の国境となった場所である。そして，この海道 の道の名前をいくつかの場所で尋ねたところ「八坂街 道」の答えがあった。海岸の低い段丘面に小面積の条 里水田が存在した。小入野川の河口で現在の浜堤を通 過する。段丘崖を西に上り, 東平から県水産種苗研究 所を経て，東電第 2 原発の北原からほほ直線で北進し て，標葉郡衙跡のあった八幡社に達する。この道路は 海上交通を補佐する古代道である。その結果, 条里, 郡 衙，廃寺などが古代道に沿って海岸近くに立地してい る。日本海と異なり, 船が海岸に沿って航海したので, 海道も海沿いになったようである。 


\section{近世阿武隈川舟路の本内河岸・鎌田河岸について}

\section{安田初 雄}

寛文 4 年 (1664), 信夫。伊達両郡が天領となり，信 達の御城米を江戸へ迴漕するために，同 5 年，江戸の 商人渡辺友意が幕府の許を得て, 福島から水沢までの 間の阿武隈川の舟路を開き，寛永 14 年 (1637) に開始 していた水沢以下荒浜迄の舟路に接続させた。

福島・瀬上などの諸河岸はその時開かれたが，本内 河岸は可成おくれて, 郡中願による新期河岸として, 宝 暦 7 年 (1757) に開設された。享和元年 (1801)，本内 村か丸子・南北矢野目等と共に, 足守藩の分領になる と，天領に残った鎌田村に河岸を移したかと思われる が，本内河岸の廃止及び鎌田河岸の開設年度はともに 定かでない。またこの両河岸の所在位置も明確でな かった。こうして本内河岸は本内字上台の東側の紺屋 渡しに所在したとする如き謬説もあった。

本内・鎌田附近の阿武隈川は, 甫及の洪水で流路も 変り, 土地の様子が著しく変化したこと, 残された史 料が少ないこと等で, 本内河岸等の位置の推定を困難 にしたかと思われる。このほど筆者は断片的な資料を つなぎあわせて，その位置の推定を試みた。

志田正徳は天保 12 年 (1841) 成稿の『信達一統志』 で, 本内郷につき「東の方は大熊川なり, 津頭あり紺 屋船場と云」と記述したが，その紺屋船場は天保 8 年 の本内村絵図に示された丸子村東端と本内地内との間 にある「横渡場」である。この渡しの東の本内地内に は荒野があったとみられる。國領検地で本帳に記載さ れた筈の古い開拓地である。享保の初めまでの阿武隈 川は, 本内村の東で, 中島村との境を流れていたが, 享 保 15 年（1730）の洪水で, 流路が変り, 本内・鎌田を 貫流して瀬上に向ったから，この荒野は分断されてし まった。そして耕作場渡しを開いたのが, 最初の紺屋 渡し, 即ち荒野渡しであろう。その位置は享保 17 年の 本内村絵図で推定される。それが 20 数年後に, 本内河 岸になる。

鎌田河岸は鎌田字河岸前にあった。ここは保原道の 渡船場である。近くの低い段丘上の黒須に,「かしくら」 と俗称される畑があり，明治初年迄，礎石も残されて いて，倉跡だったとされている。本内河岸同様に鎌田
河岸もお沶かた 10 月下旬以降, 翌年 3 月上旬までの間 の特定の日に限って，舟積に使用されるから，渡船場 が河岸とされても，大して不都合は生じなかったと思 われる。

本内・鎌田・丸子及び南北矢野目の五ケ村が，宝暦 7 年桑折代官所に仮河岸開設願を出したが, 小鵜飼舟 定請負の渡辺十右衛門はその開設に難色を示した。そ の理由は定かでないが，かつて福島河岸組であったこ れら五ケ村が，瀬上河岸組に変ったこと等が一因でな かろうか。この変更には渡辺も同意はしたけれども,当 時経営難におちいっていたから, 下流の河岸組に変れ ば，その分運貨収入が減少するので, 小鵜飼舟定請負 にとって都合のよいことではなかった。

それで代官所にも依頼し,定請負と折衝をかさね,小 鵜飼舟を本内に廻すのに増銭を支払うことで決着し た。この増銭の制度は上総屋に請負が代っても続いた。

筆者が先に阿武隈川水路図の紹介をしたとき，この 水路図に本内河岸あるいは鎌田河岸が記されていない のは，宝暦 7 年以前の古い舟路図を，江戸の絵図師が そのまま模写したためだろうと述べたが，そうではな く,この両河岸は他の河岸とは別扱いとされたために, 水路図に記載されなかったのかも知れない。はたして そうかは，今後の課題である。

上記の事情でも推察されるように，廃藩置県迄の阿 武郎川の水運は，水沢・波上を境にして，その上流の 福島迄と, 下流の荒浜迄とでは, 水運の仕組・制度。 事情等が，全く相違していた。それでその相互の乗入 れも，平常時は許されなかった。それ故，本内河岸に 舼船をおいたとか，そこから荒浜まで小鵜飼舟を下航 させた等とする見解は, 妥当でない。廃藩置県後は制 度が変り, 何人かの迴漕業者が, 福島から荒浜までの 間で，下り荷ばかりでなく，上り荷も廻漕することが 自由になった。こうして明治 20 年の東北線開通まで, それが継続した。但し，鎌田河岸は廃され，舟戸河岸 に変ったとみられる。因に，上流の矢吹東方から三春 西部までの近世の水運は，また別の仕組であった。 


\section{システムインテグレーターと地理学}

——環境情報社会論序説——

\section{金 安 岩 男（慶應大）}

本報告では，近年の情報技術進歩が地域形成とどの ような関わりを持つのか，そして変化の激しい環境情 報社会において必要な取り組み方は何なのかについて 考えてみたい。

初めに $6 \supset$ つ代表的な情報技術革新のインパクトを とりあげる。ついで，自己再組織化型の地域形成の展 開図式を説明し，その典型的な例として，シリコンバ レーの情報集積型の地域形成の特徵を紹介する。そし て, 情報ネットワーク社会には個人や地域自体の探索 学習能力が必要なことを主張する。

最後に，現代ならびに近未来の環境情報社会におい ては，システムインテグレーションの考え方がこれま で以上に重要となり, とくに地理学者が持ち合わせて いる能力が生かせることを提案する。

めざましいスピードで進化している情報環境の変化 に寄与するものとして，6つの代表的な情報技術革新 の側面,つまり，1）デバイステクノロジーの連続的な 革新，2）コンピュータシステムの利用形態の進化， 3）ネットワーク技術の進化，4） $\mathrm{HCI}($ ヒューマン・コ ンピュータインタラクション) の革新，5）マルチメ ディア処理技術の進歩，ならびに 6）情報インフラの 整備，の各インパクトがある。これらの情報技術革新 は地域形成に強い影響を与えている。

報告者が考える地域展開の構図は次のようなもので ある。地域はさまざまな要因の影響を受けつつ，地域 資源である〈人・モノ・カネ・情報〉などを活用しな がら，その地域が備えている生産技術，経営能力など を使って，さまざまな「もの」や「コト」をつくりだ している。この状況は変化する環境に対して, 地域が いかにうまく適応しながら，他の地域との差異性を地 域競争力に転化せしめていくかを示している。この地 域のメカニズムを地域の「環境適応システム」もしく は地域の「自己再組織化システム」と呼ぶことにしよ う。

地域は，公共的施設の基盤からなるハードなインフ ラストラクチャーと制度・運営方法などからなるソフ
トなインフラストラクチャーを基礎として地域活動を 行なうが，地域の精神的かつ実践的な盛り上がりも必 要不可欠であり, 地域振興のための運動がこの地域展 開メカニズムの潤滑油の役割を果たしている。した がって，これらの地域展開が円滑にかつ自律的に進む ような環境づくりを目指すことが行政には期待されて いる。それが環境づくり，支援システムとしての行政 の役割なのである。

次に, 自己再組織化型の地域形成が典型的に展開し ているものとして，ネットワーク志向で情報産業集積 型の地域形成を紹介することにしょう。シリコンバ レーの産業ダイナミズムは, 単一の技術や製品ばかり ではなく，地域の構成要素(人，企業，コミュニティ， 大学）が高い能力を持って扔り，それぞれが結び付い ていることから生まれている。言葉を変えて言えば, シ リコンバレーという地域ならびに地域の構成要素がそ れぞれ環境の変化に適応しながら，探索学習をおこな い，それぞれにとっての価值や意義を見出しながら， ネットワーク化されている。ある種の「関係づけ」に よる地域展開の在り方を示している。これは，情報が あるシステムに入力され，ある一定のアウトプットを 生み出すものと機械的に考无られていた視点とは大い に異なっている。

これらの地域動向は，構造変革であるリストラク チャリングや機能変革であるリエンジニアリングもさ ることながら，ソフトに組み替えを行い，テーマにつ いての意義，価值などを定義し直す「理想化設計」か ら始まっていると考えるのがよい。このことは，機会 を生み出す多様な地域形成の在り方を示唆しているの であり，情報により付加価值を生みだす価值創出地域 や都市が期待されているのである。

情報技術革新は地域の形成に大きなインパクトを与 えているが，われわれ個人や地域自体が探索学習を行 いながら，どのように自分自身の自己定位をはかった らよいかを何よりも問いかけているのである。 


\section{環境問題の認識と交通政策の変化}

\section{問題意識}

交通は技術開発と経済発展と連動した新しい交通の 出現・発展期に, 社会的投資と政策構築が求められ，そ の成果がその後の地域動向に大きな影響を与えてき た。

近代日本誕生後も, 鉄道と近代港湾の導入期および, エネルギー変革を背景に持った新幹線・高速道路・ ジェット空港整備期がこれに当り，今日における日本 列島の状況は，この最終段階を迎えようとしていると 認識する。

しかるに昨今のめまぐるしい動向は, 産業革命以降 1 世紀余の近代社会そのものが，その基調を変化させ， 新しい時代の幕開けかとも思わせる事態でもある。地 球的課題の出現や価值感の変化を伴った経済社会的問 題の背景を考えると, 新しい認識論の上に立った問題 意識と検討が求められているように思える。その一つ に環境問題の認識があり，環境問題からの接近と在り 方論の検討が必要である。本研究の基礎的問題意識で ある。

この基礎的問題意識を踏えて，今後の交通政策の新 たな検討課題を模索し，交通と地域の考察に何らかの 示唆となればということが目的である。詳細な資料解 析の上に積み上げる実証研究の課題としては，少なく とも個人研究としては大き過ぎて取り組めないが，問 題提起としての重要性は大きいと認識する。

欧米における新たな交通政策確立の背景一二つの事 例から一

この 10 年間位の間に, 欧米先進国において交通政策 が根底から変化するケースがみられる。今回はアメリ カ合衆国南カリフォルニア地域における事例を中心 に，フランスにおける TGV (高速鉄道) 整備政策の変 更も参考としつつ考察することとする。

このためロスアンゼルスとその周辺は石油発堀と共

\section{今 野 修 平 (大阪産業大学)}

に発展し，世界における先進国の中で，最もモータリ ゼーション対応でつくられた大都市圈であるといわれ ている。自動車交通に対応した都市発展は, 高速道路 網の形成と低層戸建住宅の組合わせによる低密市街地 の広域的展開という形状で進められた。また第 2 次世 界大戦前後からの経済発展と生活水準向上は，自家用 乗用車の普及が極端なまでに進み，この結果は都市発 展の基礎となった鉄道の衰退が，特に旅客輸送におい て皆無に近い水準にまで達した。一時はロスアンゼル ス開基のシンボルとも言える中央駅はスラム化が進む 都心の一角ともなり，無用の公共施設化する時もあっ た。都市内鉄道も撤去され，鉄道なき大都市として名 を馳せたのである。

ところが今やロスアンゼルスを中心とする南カリ フォルニアは，全米一の大気污染地域となり，連邦政 府からも環境改善を勧告される事態となり，この一つ として交通の政策転換が図られることになり，鉄道復 権に向けての再建構築が進められることになった。

新しい交通再編計画は概小以下のことを基本として いる。

1. 高速道路の新たな建設は，現在の計画決定路線 を除き，中心地域では原則として凍結。

2. 鉄道は大都市圈内の郊外から都心への路線と, 中心地域での地下鉄・市街路電車の組合わせで進める。

3. 通勤客の鉄道への転移を進める。

4. 広域行政と交通整備を連携して進める。

5. 鉄道建設の財源は公共補助をする。このため既 に 2 回の住民投票で計 $1 \%$ の一般消費税の増税を行な い，財源確保をした。

以上のことを基本に事業は進捗しているが，市民の 生活構造の変化や関連業界の反対等, 単純かつ円滑に は進んでいない。しかしフランス同様, 政策転換に踏 み切ったことは, 注目に值し, 今後わが国の交通政策 も環境からの取り組みが必要となろう。 


\section{メキシコにおける人口増加，国内人口移動に関する知見}

\section{1. 目的}

メキシコに扔ける人口分布やその変化に関して，首 位都市であるメキシコ市への集中 (とくに 1970 年代ま でにおいて）や，米国国境沿いの都市への集中（とく に 1980 年代に扔いて) といったことが，これまでいわ れてきた。しかし，州単位の統計のみではつかみきれ ない, 人口数十万人規模の都市に関する人口増加の動 向は，これまであまり言及されてこなかった。

そこで今回は, 人口数十万人規模の都市に関して,メ キシコ市や国境沿いの都市とともに統計分析をするこ とによって，その人口増加に関する知見を得ることを 試みた。

\section{2. 方 法}

まず資料についてであるが，メキシコの場合，州よ りも一つ下位の行政単位である郡（ムニシピオ）単位 のデータは人口センサスに記載されている。しかし, 都 市単位のデー夕は存在しない。したがって, 都市に関 する数值を直接得ることはできない。そこで，次善の 策として人口センサスを用い, 数個の郡からなる都市 圏をCONAPO（1987）によって確認できるものに関 してはその都市圈単位で，そうでないものに関しては 郡単位で分析を行うことにした。

次にデー夕についてであるが，まず，都市圈もしく は郡のなかから，1990 年において人口 10 万人以上の ものをすべてピックアップした。なお，以下では，こ れをも便宜的に「都市」と呼ぶ。それらからさらに，(1) メキシコ市，(2) 米国国境沿いに立地する都市 (3)「商 業的農業州」に立地する都市, (4)「自給的農業州」に 立地する都市，という 4 類型のいずれかに該当するも のにしぼって分析を行った。ここで，「商業的農業州」 と「自給的農業州」は，1990 年センサスと石井 (1986) をもとにした筆者独自の基準で決めてある。

最後に分析作業についてであるが，上記の 4 類型ご とに以下の二つの作業を行った。 $\mathrm{a}: 1940$ 年代から 1980 年代までの, 都市自体の人口の年平均増加率の分 析をし, 各々の類型の人口増加の動向がメキシコのマ
过正 行 (東北大・院)

クロ経済によく対応しているかどうかを調べた。b： 対応の悪い類型に関しては, 1980 年代に限定されては いるが, 人口の年平均増加率と, 製造業就業人口の増 加率や，その都市が立地する州の，国内州間人口移動 における転入超過率との，相関関係の分析を行い，実 情をより詳しく把握することを試みた。

3 . 結 果

前章 $\mathrm{a}$ の分析の結果, メキシコ市, 国境都市に関し ては,マクロ経済と人口との対応がみられた。まず, 80 年代に抢ける，輸入代替工業から輸出指向型工業への 変化と，前者における人口停滞，そして後者における 人口の急成長との関連がみられた。次に，商業的農業 州に立地する都市に関しても，60 年代後半の農業生 産・輸出の頭打ちと，70 年代における人口増加率の低 下との関連がみられた。

それに対して，自給的農業州に立地する都市に関し ては，マクロ経済と人口との間に明確な関連がみられ なかったので, b の分析を行った。その結果, 国境都市 と比較して，製造業就業人口の伸びが相対的に低いに もかかわらず，ほぼ等しい人口増加率 (年率 $2.8 \%$ ) を 示していること，それから，州全体では人口が流出し ているのにもかかわらず，都市自体は，それとは逆に 人口を大きく成長させていることが，明確になった。

ただし今回抢こなったことは，統計の分析だけであ り，したがって，このような結果をもたらす原因やメ カニズムに関しては，ふれることができなかった。

\section{参考文献}

石井 章 (1986)：メキシコの農業構造と農業政策。ア ジア経済研究所。

CONAPO (1987): Características principales de la migración en las grandes ciudades del país. Resultados preliminares de la encuesta nacional de migración en áreas urbanas (ENMAU). Consejo Nasional de Población (CONAPO), México. 


\title{
中部日本における出生率の地域差と先の要因
}

\author{
星野忠祐（愛知教育大・院）・石澤 孝（信州大）
}

戦後のベビーブーム以降我が国の出生率は低下を続 けた。1989 年には「1.57 ショック」という言葉を生み, その後も出生率の低下は続いている。このような出生 率低下は人口構造や社会経済に影響を及ぼし,今後, 若 年労働力の不足や高齢社会の到来が予想されている。 そこで，本研究では全国水準よりも出生率の高い中部 日本を保健所の管轄地域を基本とした地域に分けて, 出生率の地域差とその変動要因を明らかにすることを 目的とする。なお，ここで中部日本としたのは新潟。 富山・石川・福井・山梨・長野・岐阜・静岡・愛知・ 三重県の十県である。

まず 1980 年と 90 年について, 15〜49 歳の年噛 5 歳 階級別出生率を合計した合計特殊出生率についての検 討を行った。その結果, 県庁所在地执よ゙その周辺地 域に合計特殊出生率の高い地域が多く観察された。次 に年齢階級別出生率を観察したところ，25～29 歳では 県庁所在地および人口 30〜 50 万人規模の都市におい て出生率の低い地域が確認された。一方，出生率が高 い地域は北陸地方に多くみられた。30～34 歳の出生率 は甲信越地方に出生率の高い地域が多くみられた。

合計特殊出生率, 年齢階級別出生率の変化を検討し たところ，合計特殊出生率の低下が著しいのは県庁所 在都市および人口 30〜 50 万人規模の都市の周辺地に みられることが分かった。次に年齢階級別出生率の変 化について検討したところ，25～29 歳においては，北 陸地方の出生率の低下があまり見られず，甲信越地方 及び静岡県での著しい低下が認められた。30〜34 歳に おいては，内陸山間地域で出生率が増加していること が確認された。

そこで，出生率変動要因を考えるためにパス解析を 行った。具体的には職業部門別女子就業率，年齢階級 別女子就業率, 世帯・住居, 年歯階級別有配偶率が出 生率に関係しているとの仮説をおいてパスダイアグラ ムを作成し，各変数が直接・間接的に合計特殊出生率 とその変化に及ぼす影響を因果分析法によって求め た。

その結果, 80 ・90 年とも農林漁業関係と生産・運輸
関係職業からの，就業率や合計特殊出生率へのパス係 数が高くなることが明らかになった。逆に事務的職業, 販売・サービス関係職業からの, 就業率や合計特殊出 生率へのパス係数は小さくなり，職種による出生率へ の直接・間接的影響が確認された。また $80 ・ 90$ 年とも 30〜34 歳女子就業率に比べて 25〜29 歳就業率から合 計特殊出生率へのパス係数の方が大きいが，80 年より も 90 年の方がその值が小さく，その影響力が弱くなっ ていることが明らかになった。また，持ち家率から合 計特殊出生率へのパス係数から，持ち家率の高い地域 では出生率が低い，という結果が得られた。これは，持 ち家率について年歯皆級別の資料が得られなかったた めと考えられる。有配偶率についても，就業率と同様 に，25〜29 歳有配偶率からのパス係数が $30 \sim 34$ 歳有 配偶率の值を上回っている。

1980 90 年の出生率変動の要因分析を同様に行っ たところ，職業部門別就業率の変化から出生率低下へ のパス係数は，生産・運輸関係職業 (0.206) が最も大 きい值を示した。間接効果をみると，販売・サービス 関係職業から出生率低下への効果が 0.098 と最も大き な值を示した。しかし，直接効果と間接効果の合計值 からみると，職種の違いによる出生率低下に及ぼす影 響は少ないものである。また, 就業率の変化から出生 率変化へのパス係数は, 25〜29 歳で-0.195, 30〜34 歳 でー0.082 となり，25〜29 歳における就業率増加が高 い地域ほど出生率低下が著しいと解釈できる。世帯。 住居に関する変数の変化から出生率低下へのパス係数 は，核家族世帯率の変化で-0.031，単独世帯率の変化 でー0.248, 持ち家率の変化でー 0.187 という值を示し た。つまり核家族世帯率が増加しかつ単独世帯率の増 加している都市部において, 出生率低下が起こってい るものと考えられる。有配偶率低下から出生率低下へ のパス係数は 25〜29 歳で 0.371，30〜34 歳で-0.134 という值を示した。25～29 歳のパス係数は 11 変数中 最も大きな影響力を持ち，この年齢階級での晚婚化が 出生率低下に及ぼす影響の大きさが確認された。 


\section{農地の買収・壊廃にともなう農家の対応}

——長野市長沼地区の場合——

$$
\text { 竹 内 元 生 (東北大・院) }
$$

開発に伴う用地買収の対象が農地である場合，一般 にその土地の利用形態が買収時の農家の対応に少なか ら婄響を与えると考元られる。それに加え，各世帯 の経済状況, 就業状況, さらには行政側の対応等が様及 な影響を与えることが予想される。そこで本研究では, 開発に伴う農地買収が農家に対して与える影響を，主 として農家の対応の側面を中心に分析した。

事例として，北陸新幹線の車両基地が建設される長 野市近郊農村の長沼地区に抢ける, 農地面積 18 ha, 地 権者計 162 人に及ぶ用地買収を調査したので，その結 果を報告する。なおこの車両基地は，調査時点の 1995 年現在，まだ建設中であった。

研究方法としては, 地域の事情をよく知る農家, 買 収規模の大きい農家，代替地を取得した農家を中心に 聞き取りを行い, リンゴ生産農家としての状況を，長 野県農協地域開発機構が 1990 年に実施したアンケー 卜結果から分析した。今回は特に，代替地の取得と補 償金の獲得について，その状況と過程にみられる農家 対応の仕方に焦点を絞った。分析結果は，以下のとお りであった。

まず第 1 点は, ほとんどの農家は, 初めから代替地 を希望せず補償金を獲得したという点である。この理 由として，非常に高額な補償金（農地ではなく宅地見 込み地として金額が決定， $10 \mathrm{a}$ 当り 3〜 4万円であ り, 通常の農地売買の 10 倍に当る), 世帯の経済的要 因が第 1 に挙げられる。また, 後継者不足, 高齢化等 の労働力的要因や, 長沼地区が長野県リンゴ産業の中 心に位置し，リンゴ産業に極めて特化している事実も 無視できない（内部的要因として規定される）。

一般に, 営農意欲が高ければ代替地を取得し農業経 営の拡大を目指すと考えられるが, 実際, 営農意欲が 高い農家であっても代替地を希望していない。これは 現在のリンゴ産業がょり一層の労働集約化傾向にある ことと関連している。長沼では，伝統的に地元市場へ の近接性を生かした出荷や国道 18 号の直売所での販
売等，個人出荷の割合が非常に高く，現在では宅配便 販売を利用する農家が増えている。こうした個人出荷 の拡大は，リンゴの輸入自由化，消費者側のブランド 意識, 品質重視に対する農家の戦略として捉えられる。 このため, 品質向上のための葉摘み, 玉回し, さらに は宅配便に関する細かい作業が増え，労働集約化の道 をたどらざるを得ない状況にある。

用地買収によって生じた余利労働力を，代替地取得 による面積的，量的拡大に費やすのではなく，他の農 地に余計に費やすことで，さらなる品質向上に努めて いると考えられる。

第 2 点は，代替地を希望する例も若干見られたとい う点である。この場合農家は, 自家製米への欲求や相 続税等をその理由として挙げている。また交渉の段階 で，代替地と補償金を分割して得ることが不可能なこ とや, 行政側の対応不足の現れでもある, 代替地の条 件が悪いといった取得上の不都合が生じ, 結果的に代 替地を取得した地権者はわずか数人であった（外部的 要因として規定される)。

このとき代替地の取得の有無で営農意欲の差を判断 することはできないが, 水田の代替地を取得したか,リ ンゴ畑の代替地を取得したかという点では明らかに営 農意欲に差があり, 代替地の地目差は営農意欲の差の 現れと言える。

第 3 点は, 都市域周辺においてみられる, 農地の資 産的価值化とそれに伴う農地の荒廃化が, この地域で も進展してくる可能性がみられる点である。長沼地区 は長野市近郊にあっても, その農業形態は純農村的色 彩が強い。しかし今回のように高額な代金で用地買収 が行なわれた場合, 営農意欲の低下, 農地への資産的 価値の増大等, 今後の農業経営に何らかの影響を及ほ しかねない。また，これまで以上に労働集約化が進み， なおかつ高齢化, 後継者不足によって面積的縮小を余 儀なくされれば，従来の純農村的土地利用から都市近 郊的土地利用への展開は一層進むものと思われる。 


\section{都市近郊農村における農業的土地利用の持続性と变移性}

—— 前橋市近郊の養舂農村の事例

都市近郊において, 農業的土地利用の変化プロセス とそのメカニズムを分析・検討することは, 農業地理 学や都市地理学の主要な研究テーマの 1 つである。そ こで, この研究は前橋市近郊の元総社地区を事例にし て，農業的土地利用がどのようなプロセスで変化して きたかを分析し，その変化要因とメカニズムを検討し た。養虫農村であった元総社地区は, 前橋市近郊に位 置し, 前橋一高崎コナーベーションの幹線道路に隣接 しているにもかかわらず，農業的土地利用から都市的 土地利用への変化が相対的に緩やかなことに地域の特 徵がある。また前橋市全体からみても, 元総社地区で は桑園が残存し，畑地が増加する傾向にある。

元総社地区の 1974 年の土地利用は, 土地条件を強く 反映し, 桑園や養蚟農家が台地に, 水田が谷に分布し ていた。幹線道路に沿って一般住宅や店舗・工場, あ るいは駐車場が散在しているが, 全体的には桑園が卓 越していた。1986 年になっても, 台地の桑園と谷の水 田という枠組みは維持され, 桑園が卓越していること に変わりない。しかし台地では, 普通畑が点在するよ
菊地俊夫（都立大）・堤 純（北海道大）

うになり，一般住宅の建設も増える傾向にあった。

1994 年になると, 台地上の桑園が著しく縮小し, 谷 でも水田の縮小が目立つようになる。多くの一般住宅 や店舗，駐車場が幹線道路に沿って台地上にまとまっ て立地するようになり, 農業的土地利用から都市的土 地利用への転換が決定づけられた。また, 幹線道路か ら離れた台地上では, 普通畑が依然として目立つ傾向 にあり, 長ネギなどを集約的に栽培する畑と, 多種類 の野菜を自家用に栽培する畑とが混在している。

1974 年から 1986 年にかけては, 桑園から普通畑へ や普通畑から水田への変化, あるいは普通畑から一般 住宅への変化などが分散的に生じているが，農業的土 地利用は堅持され，持続性を反映したものになってい る。それに対して, 1986 年から 1994 年にかけては, 桑 園から普通畑への変化が卓越しているが, 農業的土地 利用から一般住宅や店舗など都市的土地利用への変化 も急激に拡大している。つまり, 農業的土地利用は都 市的要素の侵入によって，変移性の性格を強く反映す るようになったといえる。

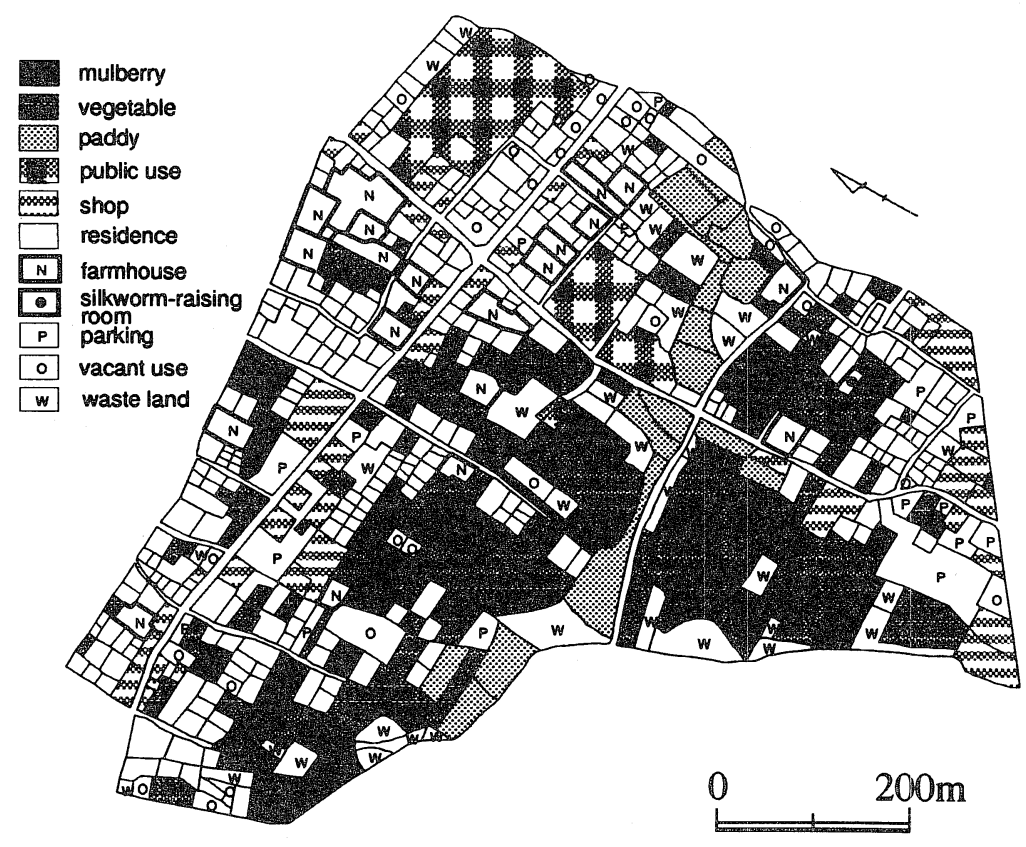

図＼cjkstart前橋市元総社地区における土地利用（1994 年）（現地調查により作成）。 
以上の分析から, 前橋市元総社地区の土地利用の変 化プロセスは，農業的土地利用の持続性を反映する段 階と, 農業的土地利用の変移性を反映する段階とに大 きく区分されることがわかった。持続性を反映する段 階では，都市的要素の侵入や農家兼業の深化氾もかか わらず，農地利用の集約化や高度化を，あるいは省力 化を図ることにより，農業的土地利用は維持されてき た。一方，変移性を反映する段階では，農家率が低下
し混住化が進むことで，農業的土地利用の持続性は崩 れていく。したがって, 都市近郊での農業的土地利用 は，兼業化に対してある程度，持続性を維持すること ができるが，混住化に対しては持続性を保つことが難 しくなる。そして，桑園などの樹木農業は，都市近郊 の混住化を遅らせ, 農業的土地利用の変移性を阻止す る要因として機能することもわかった。

\section{福島県高郷村における農家の兼業化進展過程}

本発表は農家における兼業化の基本的次元である 2 種恒勤兼業化を農家世帯及び世帯員レベルで把握し， 兼業化が農家及び農家世帯員レベルでは実際にいかな る変化であったのかという意義付けとともに従来的な 評価の再検討を行おうと試みたものである。対象地域 は 1980 年代以降に 2 種恒常的勤務兼業化が顕著で あった福島県高郷村夏井集落とし，聞き取りによって 農家の兼業化過程を復元し世代別，専業農家及び 1 種・2 種兼業農家別に検討した。その結果は次のように 概説される。

対象集落においては，伝統的出稼ぎとして屋根莫き 出稼ぎが何例かみられたが，本格的な農家の兼業化は まず第 1 世代男子が 1960 年代後半から 1980 年にかけ て，主に関東南部への出稼ぎ兼業という形態でその端 緒を開いた。第 1 世代の女子は一部が製造業，建設業 に就業したものの対象期間を通じて農業専従であり, 世帯として農業の主体的労働力であった。そして第 2 世代以下が他出している場合，世帯としては専業化し 高齢化した第 1 世代による農業が継続されている。

さらに 1960 年代後半以降, 第 1 世代の「子」にあた る第 2 世代が新卒期を迎えるとほぼ全てがその当初か ら恒常的勤務兼業に就業したが, 全く農業から離脱し ているわけではなく農業へは「休日のみ就業」という 形態で関わっている。恒常的勤務兼業は広範な通勤を 可能にした自家用車通勤によって支持され，兼業の職 種は 1970 年代以降会津地方においても顕著であった 工場進出に対応した製造業と, 役場職員・農協職員等 の公務員系就業に特徵を持つ。第 2 世代男子の「妻」に あたる第 2 世代女子とその「子」である第 3 世代は農 業への就業において世帯の第 1 種と第 2 種兼業間，世 代間, 就業の業種間に明瞭な差異がある。それは第 2 種 兼業農家に扔いて，30 歳代以下の公務員・専門職系就

\section{関 根 良 平 (東北大・院)}

業者の場合「恒常的勤務のみ就業」つまり全く農業と は関わりを持たず，第 3 世代に至っては全層的に農業 就業はみられない。特に公務員・専門職系就業者は今 後も農業就業にシフトする可能性は極めて薄い。

以上のように農家の 2 種恒常的勤務兼業化は第 2 世 代男子が世代交替的に新卒労働力として参加し，さら にその「嫁」にあたる第 2 世代女子が恒常的勤務労働 者として農家世帯に参加することで進展したが，それ は第 1 世代にとっては当初は男子が出稼ぎに就労した ものの，機械化による省力化を図りながら対象期間を 通じて何ら変化することなく農業へ労働力を投下して きたのであり，その意味では全く消極的なものではな かったといえる。第 2 世代にとっても，自らの労働力 を農業中心に投下しなくとも世帯としては十分に農業 経営が可能であった。それは第 2 世代女子にとっては 言を俟たず，第 2 世代男子にとってもそのほとんどが 新卒期から恒常的勤務兼業に就業していたことからも 明白である。よって対象地域においては 1995 年現在ま では, 農家の 2 種恒常的勤務兼業化が即離農・脱農に つながるものではない。しかし現在の第 1 世代が死亡， 高齢化した場合, 一挙に世帯としての農業労働力が激 減し「非農業化」が進行する可能性がある。

また，上記のような過程は第 1 世代から第 2 世代以 下に農家が世帯として継承される場合に顕在化する が，特に第 2 世代以下が他出している場合は高齢化し た労働力のみの生産年齢人口を欠く専業農家の増加を もたらしている。このメカニズムによって現在までよ く保持されてきた世帯数が世帯としての再生産が停止 した状況にあるこの層から消滅していくことが予想さ れる。これらの農家が今後世帯を維持しうるのかどう かは地域の農業維持という点からも重要である。 


\section{新都市計画法と都市化の進展}

中川重（山形大）

昭和 43 年 (1968 年) 6 月, 約 50 年にわたってわが 国の都市形成の基本法であった都市計画法（旧法）に 代わって新都市計画法（新法）が制定された。新法は 戦後の急速かつ無秩序な都市化に対して，区域区分制 度（いわゆる線引き）と開発許可制度を導入したもの で，市街化区域と市街化調整区域を設けることによっ て，無秩序・無計画な市街化（スプロール）を抑制し， 良質な市街地の整備・形成を図るものであった。既成 市街地とおおむね 10 年以内に市街化を図るべき区域 である市街化区域の設定は，区域指定が広すぎたとか， 区域内の都市基盤施設整備の遅れやミ二開発, 既成市 街地の住環境の改善には, 必ずしも有効に機能し得な かったなどの問題点が指摘されているが，この制度の 定着は,スプロール問題には一定の成果をもたらした。 とくに線引きを導入した地方都市では, 計画的な市街 地の創出と整備に果たした役割は大きいといえる。

しかし, 新法制定後の市街地の拡大（都市化）状況 やその地域差（都市間差異）が十分に把握されている とはいい難い。そこで本報告は北海道・東北地方の線 引き都市を対象にデータを整理し, 市街化区域設定以 後の都市化の状況について予察的考察したものであ る。市街地の拡大（都市化）の状況については，市街 化区域と人口集中地区（以下 DID）における面積及び 人口の変化や, 市街化区域に対する人口集中地区の比 率などによって把握した。

平成 6 年度末，市街化区域は全国で 333 区域，398 市，443 町村に設定され，その面積は約 1 万 4 千 $\mathrm{km}^{2}$, 国土面積の約 $3.7 \%$ ，人口で約 8.1 千万人 $(65.5 \%)$ に 達し, 昭和 50 年度末に比して各々 $13.7 \%, 21.8 \%$ 増加 している。一方, 実質的な都市地域である DID の市街 化区域に対する比率をみると, 両年度のほぼ 25 年間に
面積で $51.9 \%$ から $83.1 \%$ へ,人口で $83.9 \%$ から 96.2\% へと増加しており,またDID の拡大は市街化区 域の拡大に比して面積で約 3 倍, 人口で 1.5 倍にも拡 張しており，市街化区域とDID と間隔が減少し, 全国 的には市街化区域内での都市化が確実に進行したこと を物語っている。

しかし, 北海道・東北地方における市街化区域はわ ずかに 28 区域，85市町村に設定されているに過ぎな い。岩手・秋田両県では唯一盛岡都市圈と秋田都市圈 しか指定されておらず，全般的には区域区分制度の導 入による都市地域の整備・拡大は図られなかった。DID 面積の拡大は市街化区域面積の拡大に比して全国並の 約 3 倍に達しているが, DID の市街化区域に対する比 率をみると, 両年度間で面積で $37.9 \%$ から $60.3 \%$, 人口で $74.7 \%$ から $85.7 \%$ への増加に止まっている。こ れは市街化区域内における都市化が全国並には進展し なかったことを示しており，線引きが当初からかなり 広く実施されたことが影響していると思われる。それ は現在でもDID の市街化区域に対する比率が $50 \%$ に 満たない市町が, 主として中心都市に隣接して存在し, 今後の都市化地域の予備軍として, あるいは緩衝地域 として位置づけられているとも考えられる。

今回の報告では，個別都市に関する特徴については 省略するが，今後は個別に用途地域指定による諸制約， 土地区画整理事業や地区計画等の導入，あるいは市街 化調整区域における大規模開発（主として宅地）との 関連等々の具体的な都市整備計画の実施状況やその動 向の実態把握にもとづいて分析を重ね, 新都市計画法 が 25 年間に都市地域の整備や都市化に果たした役割, すなわち市街化区域の設定が都市化に果たした効用に ついて明らかにする必要があろう。

\section{都市内事業所密度の法則}

都市内人口密度モデルの最初のものであるクラー ク・モデルは, 都市内部の人口の空間的分布を示すに はかならずしも有効ではないとして，これに替わる 種々のモデルの提案がおこなわれているが，札幌，仙 台, 広島, 及び福岡の 4 都市について, 事業所統計の

\section{大 友篤（日本女子大）}

地域メッシュ・デー夕を用いて，クラーク・モデルを 適用すると, 事業所密度への適合度は, 常住人口密度 よりもかなり高いことが明らかになった。

また，事業所の経済活動の種類である産業別にク ラーク・モデルを適用すると，産業別にも，このモデ 
ルが適合することが示され, 同時に, 回帰直線のパター ンが, 4 都市について共通に, 産業によって異なること が明らかにされた。このことは, 都市の内部において， 事業所の空間的分布が産業別に一定の規則性を有して いることを意味している。とくに，回帰係数すなわち 密度の傾斜度が産業によってほぼ定の数值を示すこ とは，産業によって事業所の都市内における空間的分
布が一定であるという規則性を示していることを示唆 している。つまり,この值が高い卸売業や飲食店は, 都 心部に集中した分布を示し，この值が低い公的サービ スや，製造業，建設業などの事業所は，都市内に扔い て分散的な分布を示し，これら以外の産業は，中間的 な分布パターンを示すことを意味している。

\section{都心社会の変動と「町おこし」運動 「伝統的なるもの」をめぐって -}

遠 城 明 雄（東北大）

\section{1. 問題の所在}

多くの大都市の都心地区は長年にわたり，人口減少 や居住環境の悪化など様々な生活問題に直面してお り，特に近年は「バブル」経済の後遺症を強く受けて いる。本研究では，このような都心社会の変動に対し て居住者が主体的にどのような取組を扔こなってきた のか，またそこにいかなる問題があるのかについて若 干の検討を抢こなう。研究対象地域は，福岡市博多部 であり，この地区では急激な人口減少（1955 年を 100 とすると 1991 年は 32.5) と高齢化，および単身者世帯 の増加が顕著である。まず伝統的行事である「博多祇 園山笠」を支える諸社会集団の変化を概観し，次に「町 おこし」運動をめぐるいくつかの問題について取り上 げる。

\section{2.「伝統的行事」の現在}

1945 年以降の祭礼集団の変化は大きく次の三つの 時期に区分されると考元られる。

(1) 復興期：山笠は戦災からの復興のシンボルと して大きな役割を果たした。組織上の大きな変化とし て従来まで博多部の「七流」だけに限定されていた祭 礼への参加が，博多部の他の町や博多部以外の町にも 正式に認められたことが挙げられる。

（2）停滞期：参加者が次第に減少し,流によっては 祭礼の運営に窮するところも出てきた。特に 1965 年前 後の町名町界変更によって従来までの町と流の構成が 変更を余儀なくされ，祭りの運営の大幅な見直しがお こった。それによって流の内部で新旧の町の間などで 意見の相違が生じる場合も増加した。

（3）表面的な安定期：外部からの参加者が増加し， 祭りが全国的に有名になる一方で，居住者が大幅に減 少したことで祭りの運営の中心となる後継者不足が心 配されるようになっており，実質上，消滅した町もあ
る（93 年 7 月におこなわれたアンケート調査でも約 7 割が外部からの参加者という結果が出ている)。多くの 流では町に住む人のみが役職に付くことが可能である が,現実にこうした規則が保持しにくくなっており，そ れは年齢階梯制に基づく運営をも困難にさせつつあ る。

こうした厳しい現状に対して，最低限の定住人口を 確保するための様々な動きが住民の内部からでてき た。

3.「町おこし」運動と「伝統的なるもの」

現在博多部には複数の町抗こしグループが存在す る。また 1994 年には住民組織として「町づくり協議会」 が発足し，自治体や地元企業との共同も模索され始め ている。このうち 9 年前に結成された最も古い町抢こ しグループは，定住人口の増加を最大の目標に，機関 誌を発行して博多部の現状を外部の人久に広く認識し てもらったり，維持が困難になった町ごとの小さな祭 りに協力するなど地道な活動を続けている。しかしな がらこうした諸集団の活動は相互協力に必ずしも成功 しておらずむしろ対立する側面が強いといえる。ここ ではその原因の一端を理解するために，住民が「伝統」 をどのように表象しているかという点に着目した。

住民は伝統という言葉を二つの意味で使用している と考えられる。第一は自らの集団の内部を統合するた めの論理としてであり，第二は住民が自らの活動の正 当性を外部の人々に積極的に説明し，納得させるため の論理としてである。後者の意味で伝統は過去との連 続性ではなく，過去の積極的な再構成と再活用として 理解される必要があり，例えば「伝統を守る」という 主張は，過去の忠実な継承ではなく，あくまでも現在 の生活を維持するための創造的な努力である。よって 伝統を主張することは都心社会の変動に対する住民の 
能動的な対応であり，こうした文脈から切り離された 伝統は想像上の産物であるといえる。但し伝統の第一 の特徵は, 常に過去への郷愁とその不可能性から生じ る現在への抑圧を含んでいる。特にアイデンティティ の強調は，「博多」というイメージに対する外部からの 視線が意識される際に顕著になるが，山笠がもってい
る多様な集団の混淆という側面を覆い隠してしまう。 以上のことから伝統は, 両面価值的なものとしてそ の創造的側面と統合的側面の間が拮抗する場になって おり，他の社会的関係との結びつきのなかでその固有 の力が生じると考えられる。 